IRINA CHACHULSKA

INSTYTUT SZTUKI, POLSKA AKADEMIA NAUK

\title{
O TRZECH ZABYTKACH MUZYCZNO-LITURGICZNYCH Z KOLEKCJI BAWOROWSKICH PRZECHOWYWANYCH W BIBLIOTECE NARODOWEJ
}

W śród muzycznych zabytków liturgicznych pochodzących z kolekcji Baworowskich, które wpłynęły po wojnie (w 1945 r.) do zbiorów Biblioteki Narodowej, poza pontyfikałem katedry lwowskiej (PL-Wn I2499 IV) znajdują się trzy rękopisy muzyczno-liturgiczne - graduał cysterski i dwa fragmenty ze śpiewami oficjum i liturgii mszalnej. Są to:

I) PL-Wn I2496 IV: f. 98+II, pergamin, 390 x $280 \mathrm{~mm}$, oprawa: deski i skóra, sygnatury dawne: N.2.I.a/2. - X.A.3. - Baw. 2. - BN akc. 9757 (il. I) ${ }^{\mathrm{I}}$,

2) PL-Wn I2497 IV: f. 5+II, pergamin, $380 \times 290 \mathrm{~mm}$, oprawa: tektura i pergamin, sygnatury dawne: N.2.I.a/3 - X.A.4. - Baw. 3. - BN akc. 9758 (il. 2-4)2,

3) PL-Wn I2498 IV: f. I+II, pergamin, 375 x 275, oprawa tekturowa, sygnatury dawne: N.2.I.a/4, X.A.5. - Baw. 4. - BN akc. 9759 (il. 5)3.

W odróżnieniu od dwóch fragmentów, graduał PL-Wn I2496 IV niejeden już raz był obiektem zainteresowania muzykologów mediewistów (wzmiankowany głównie pod dawną sygnaturą Baw. 2). Choć uwzględniony w dwóch istotnych monografiach - Polskie graduaty średniowieczne Jerzego Pikulika ${ }^{4}$ oraz Średniowiecze (cz. I) Jerzego Morawskiego ${ }^{5}$ - nie został jednak do tej pory zbadany w stopniu

I W postaci zdigitalizowanej rękopis jest dostępny na portalu Polona, polona.pl, https://polona.pl/item/ graduale-cisterciense,MjIzMzQ2MQ/, dostęp 3I VIII 2020.

2 Ibid., https://polona.pl/item/graduale-fragment,OTcIMTc2NDM/, dostęp 3 I VIII 2020.

3 Ibid., https://polona.pl/item/sequentia-hymnus,MTAyNzkzOTAy/, dostęp 3I VIII 2020.

4 Jerzy Pikulik, Polskie graduaty średniowieczne, Warszawa $200 \mathrm{I}$.

5 Jerzy Morawski, Średniowiecze, cz. I, Warszawa 2006 (= Historia Muzyki Polskiej I). 
satysfakcjonującym ${ }^{6}$. Co więcej, dwaj badacze podają odmienną datację i proweniencję rękopisu. Jerzy Pikulik w swojej pracy o graduałach polskich mówi o posługiwaniu się księgą przez cystersów z okręgu lwowskiego (?), datując ją na wiek XIII7, z kolei Jerzy Morawski wskazuje na przełom XIII/XIV w. jako czas powstania graduału i klasztor w Żarnowcu jako miejsce pochodzenia księgi ${ }^{8}$. Graduał jest także wzmiankowany w publikacji Janki Szendrei jako jeden z trzynastowiecznych rękopisów cysterskich prezentujących tradycję śląską pod względem pisma muzycznego ${ }^{9}$. Śląskie pochodzenie księgi podejrzewają także autorzy inwentarza rękopisów Biblioteki Narodowej, datując rękopis na II poł. XIII w. ${ }^{\text {IO }}$.

Dwa fragmenty po raz pierwszy bardziej szczegółowo opracowane zostały podczas prac związanych ze sporządzeniem wykazu poszczególnych rękopisów muzyczno-liturgicznych ze zbiorów Biblioteki Narodowej prowadzonych przez autorkę w $2018 \mathrm{r}$. (wykaz dostępny na stronie Instytutu Sztuki PAN) ${ }^{\mathrm{II}}$. Oba rękopisy okazały się wówczas interesujące z uwagi na szczególną zawartość. Już wstępne badania odsłoniły ich pierwotne przeznaczenie - służyć miały one do sprawowania liturgii w zakonie cystersów, o czym świadczą liczne elementy charakterystyczne dla cysterskiej tradycji liturgicznej.

Obecność trzech rękopisów o cysterskiej proweniencji w zbiorach Baworowskich wśród, jak się wydaje, stosunkowo nielicznej grupy rękopisów muzyczno-liturgicznych tejże kolekcji ${ }^{12}$, wydawała się nieprzypadkowa i stała się impulsem do podjęcia

6 Rękopisowi została poświęcona praca magisterska napisana przez Witolda Soleckiego, w której nie rozwiązano jednak kwestii jego pochodzenia i czasu powstania, jak też nie omówiono dalszych losów księgi, zob.: Witold Solecki, Analiza źródtowa rękopisu muzycznego ms. BAW. 2 z Biblioteki Narodowej $w$ Warszawie, Uniwersytet Kardynała Stefana Wyszyńskiego 1982 (praca magisterska).

7 J. Pikulik, Polskie graduaty, s. I4; za Pikulikiem powtarza także ks. Kołodziejczak, zob.: Zenon Kołodziejczak, „Historia chorału gregoriańskiego w Polsce”, w: Thesaurus musicae sacrae summa cura servetur et foveatur, red. Stanisław Dąbek, Ireneusz Pawlak, Lublin 2004, s. 58.

8 J. Morawski, Średniowiecze, s. 349.

9 Janka Szendrei, „Notacja liniowa w polskich źródłach chorałowych XII-XVI wieku”, w: Notae musicae artis. Notacja muzyczna w źródtach polskich XI-XVI wieku, red. Elżbieta Witkowska-Zaremba, Kraków 1999, s. 194.

Io Inwentarz rękopisów do połowy XVI wieku w zbiorach Biblioteki Narodowej, opr. Jerzy Kaliszuk, Sławomir Szyller, Warszawa 20I2, s. I69.

II Zob.: http://www.ispan.pl/pl/wydawnictwa/publikacje-online/rekopisy-liturgiczne-z-biblioteki-narodowej, dostęp 3I VIII 2020. Jeden z fragmentów (PL-Wn I2497 IV) stał się później przedmiotem zainteresowań Dominiki Grabiec ze względu na obecny w nim formularz na święto Korony Cierniowej, zob.: Dominika Grabiec, „Formularz Mszy o Koronie Cierniowej z fragmentu graduału 12497 IV ze zbiorów Biblioteki Narodowej w Warszawie", w: Textus et Pictura. Średniowieczny kodeks rękopiśsmienny jako nośnik treści, znaczeń i wartości artystycznych, red. Monika Jakubek-Raczkowska, Marta Czyżak, t. 2, Studia nad skryptorium i spuścizna rękopiśmienna średniowiecza, Toruń 20I9, s. 2I-3I.

I2 O niedużej liczbie rękopisów muzyczno-liturgicznych w zbiorach Baworowskich świadczyłaby obecność na liście Kętrzyńskiego z 1892 r. jedynie dwóch zabytków, biorąc pod uwagę, iż zasadniczy trzon kolekcji powstał do roku I860, zob.: Wojciech Kętrzyński, „Biblioteka Wiktora hr. Baworowskiego we Lwowie”, Teka konserwatorska. Rocznik Kota C.K. konserwatorów starożytnych pomników Galicyi wschodniej I (I892), s. 48; Józef Szocki, „Księgozbiór Wiktora Baworowskiego - lwowskiego kolekcjonera i fundatora biblioteki”, w: Lwów: miasto, spoteczeństwo, kultura, red. Henryk W. Żaliński, Kazimierz Karolczak, Kraków 1998 (= Studia z Dziejów Lwowa 2), s. 447-455. 
dalszych badań nad trzema źródłami, których wyniki przedstawione zostały w niniejszym artykule.

Dwa z trzech rękopisów wzmiankowane są w najstarszym istniejącym opisie rękopiśmiennej kolekcji Baworowskich sporządzonym jeszcze w XIX w. przez historyka Wojciecha Kętrzyńskiego ${ }^{13}$. Listę najcenniejszych rękopisów biblioteki przygotował on i opublikował w I892 r. (Lwów), w czasie, kiedy zbiór rękopisów w bibliotece Baworowskich nie był jeszcze uporządkowany (według słów samego Kętrzyńskiego) - nie istniał żaden katalog, ani nawet inwentarz - a rękopisy nie posiadały sygnatur. Jak zastrzega sam Kętrzyński, jego celem nie było stworzenie katalogu, a jedynie udostępnienie szerszej grupie badaczy swoich, jak sam pisał, notatek, stąd rękopisy, które spotkały się z większym zainteresowaniem historyka opisane zostały bardziej szczegółowo, inne zaś tylko pobieżnie. Na końcu listy Kętrzyński wymienia dwa rękopisy muzyczne, których krótkie opisy nie pozostawiają wątpliwości, iż chodzi o graduał PL-Wn I2496 IV i fragment PL-Wn I2498 IV:

I. Tekst z nutami.

Rkp. pergaminowy zawierający kart kilkadziesiąt z XIII wieku; na końcu kilka kart z XIV wieku; inicyały ładne

2. Sequencia de s. Hedvige cum notis.

Rkp. pergaminowy złożony z pięciu kart in folio z XIV wieku; pochodzi z katedry lwowskieji

W przypadku pierwszego źródła (graduału) badacz nie podaje żadnych danych proweniencyjnych, z kolei drugie (PL-Wn I2498 IV), jego zdaniem, pochodzić miatoby z katedry lwowskiej. Jak wynika z opisu, fragment zachowany obecnie w postaci jednej karty (PL-Wn I2498 IV) liczył wówczas pięć kart. Na liście Kętrzyńskiego nieobecny jest drugi z omawianych fragmentów muzyczno-liturgicznych (PL-Wn I2497 IV), co nie oznacza bynajmniej, iż nie było go wówczas w bibliotece, gdyż, jak zaznacza sam badacz, nie wszystkie rękopisy zostały ujęte w jego spisie.

Wszystkie trzy źródła są natomiast wymienione w przedwojennym rękopiśmiennym inwentarzu (sprzed 1930 r.) biblioteki Wiktora Baworowskiego ${ }^{15}$. Rękopisy występują tu kolejno pod numerami 2, 3 i 4 z nadanymi im sygnaturami: nr 2 = X.A.3 (I2496 IV), nr 3 = X.A.4 (I2497 IV), nr 4 = X.A.5 (I2498 IV). Graduał został wpisany do inwentarza jako „Kancjonał trzebnicki św. Jadwigi” z poł. XIV w. (I360) z adnotacja "nabyty po J.Th. Mozewiuszu z Wrocławia”. Przy fragmencie I2497 IV występuje notka ze znakiem zapytania o treści „ciąg dalszy poprzedniego?” oraz adnotacja obok „był niegdyś w katedrze Lwowskiej”. Z kolei w opisie

I3 W. Kętrzyński, „Biblioteka Wiktora hr. Baworowskiego”, s. 38-48.

I4 Ibid., s. 48.

I5 Za udostępnione zdjęcie strony przedwojennego inwentarza rękopisów z Biblioteki Baworowskich zawierającej opisy badanych źródeł kieruję serdeczne podziękowania do prof. Jerzego Kaliszuka. 
I2498 IV pojawia się jedynie zapis: „ciąg dalszy dwu poprzednich”, oraz informacja, iż źródło stanowi jedna karta wyposażona w tekturową oprawę. Jeśli pod koniec XIX w. rękopis rzeczywiście posiadał pięć kart, jak rejestruje to Kętrzyński, oznaczałoby to, iż cztery karty zaginęły w samej bibliotece, a jedyna zachowana otrzymała oprawę już w bibliotece Baworowskich.

Choć opisy inwentarzowe dostarczają kolejnych cennych informacji na temat źródeł, zarazem wydają się wprowadzać jeszcze więcej niejasności i sprzeczności. Rękopis I2496 IV jest graduałem, nie zaś kancjonałem; jeśli księga pochodzi z XIV w., nie mogła należeć do św. Jadwigi, zmarłej w I243 roku. Autor opisów wydaje się być sam zdezorientowany informacjami, które podaje w odniesieniu do fragmentu I2497 IV - wpisując jednocześnie dwie notki wyrażające odmienne poglądy co do proweniencji źródła, pierwszą z nich opatruje znakiem zapytania. Nieścisłości dotyczą także samej datacji rękopisów - sugerowany w inwentarzu ten sam czas powstania źródeł (poł. XIV w.) nie jest możliwy, jako że pismo muzyczne graduału (I2496 IV) prezentuje nie tylko odmienny, ale i wyraźnie starszy typ notacji, co jest widoczne już na pierwszy rzut oka (por. il. I-4). Co więcej, sam fragment I2497 IV nie jest jednolity pod względem paleograficznym - zapisy na pierwszej karcie i czterech pozostałych bez wątpienia powstały w różnych stuleciach (por. il. 2 i 3 ).

Żadnych wyjaśnień nie znajdujemy też w inwentarzu rękopisów Biblioteki Narodowej. Jego autorzy nie łączą fragmentów z graduałem, nie podają innych danych proweniencyjnych poza samą biblioteką Baworowskich, zwracają natomiast uwage na niejednolitość paleograficzną PL-Wn I2497 IV, datując osobno poszczególne segmenty rękopisu różniące się między sobą pod względem pisma (f. I - XV w., f. 2-5 - XVIII w., karty z oprawy - XIV w. $)^{\mathrm{I} 6}$.

Gruntowna analiza trzech źródeł pod względem ich zawartości jak też aspektu paleograficznego, której wyniki przedstawiono poniżej, pozwoliła zweryfikować dotychczasowy stan wiedzy na temat samego graduału (I2496 IV), jak też wniosła wiele nowych ustaleń na temat rękopisów oraz rozjaśniają wątpliwości i sprzeczności wynikające z ich opisów zawartych w inwentarzu.

I6 Inwentarz rękopisów, s. I69. 


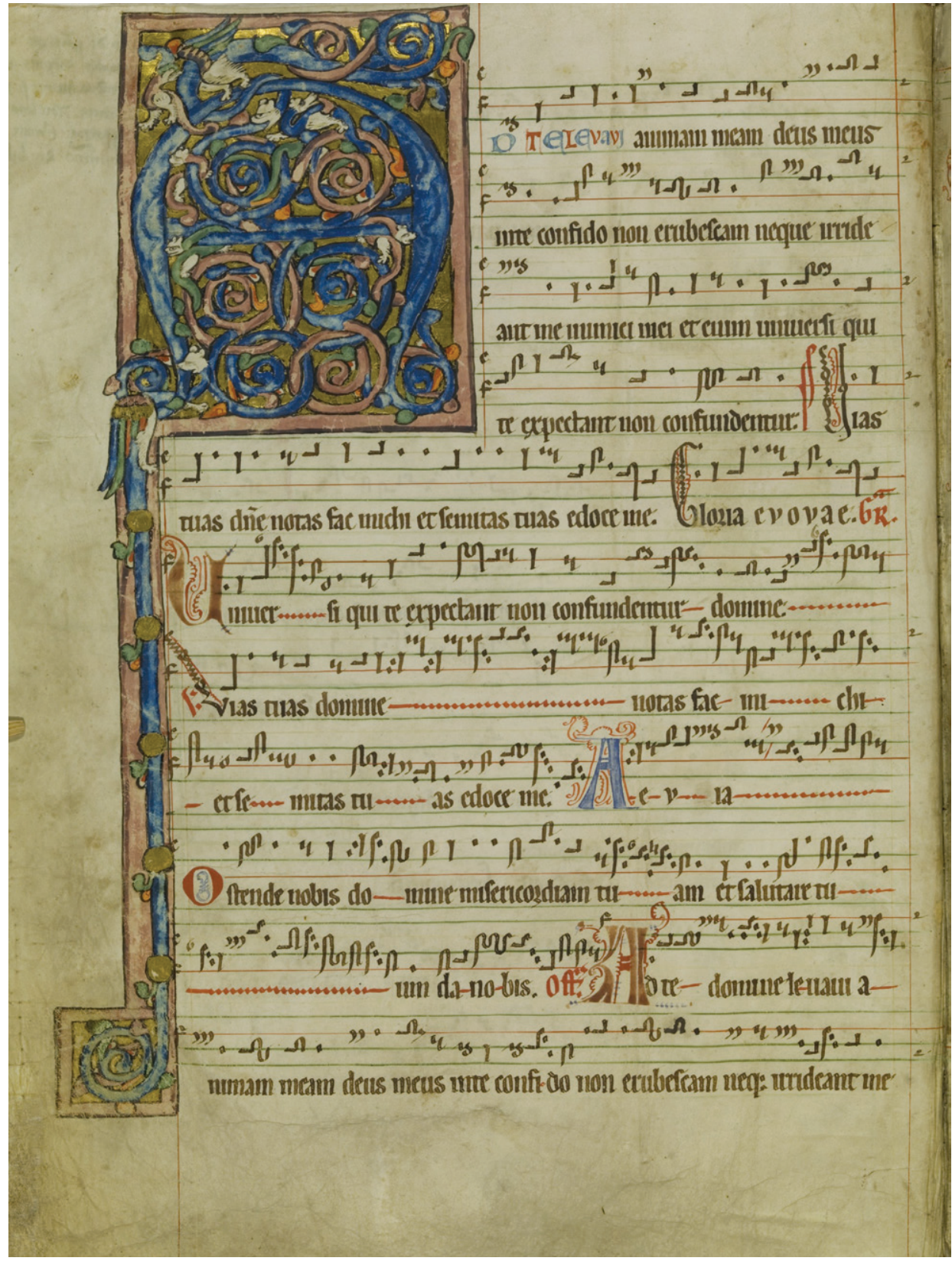

Il. I. Warszawa, Biblioteka Narodowa, rkps I2496 IV, f. Iv 


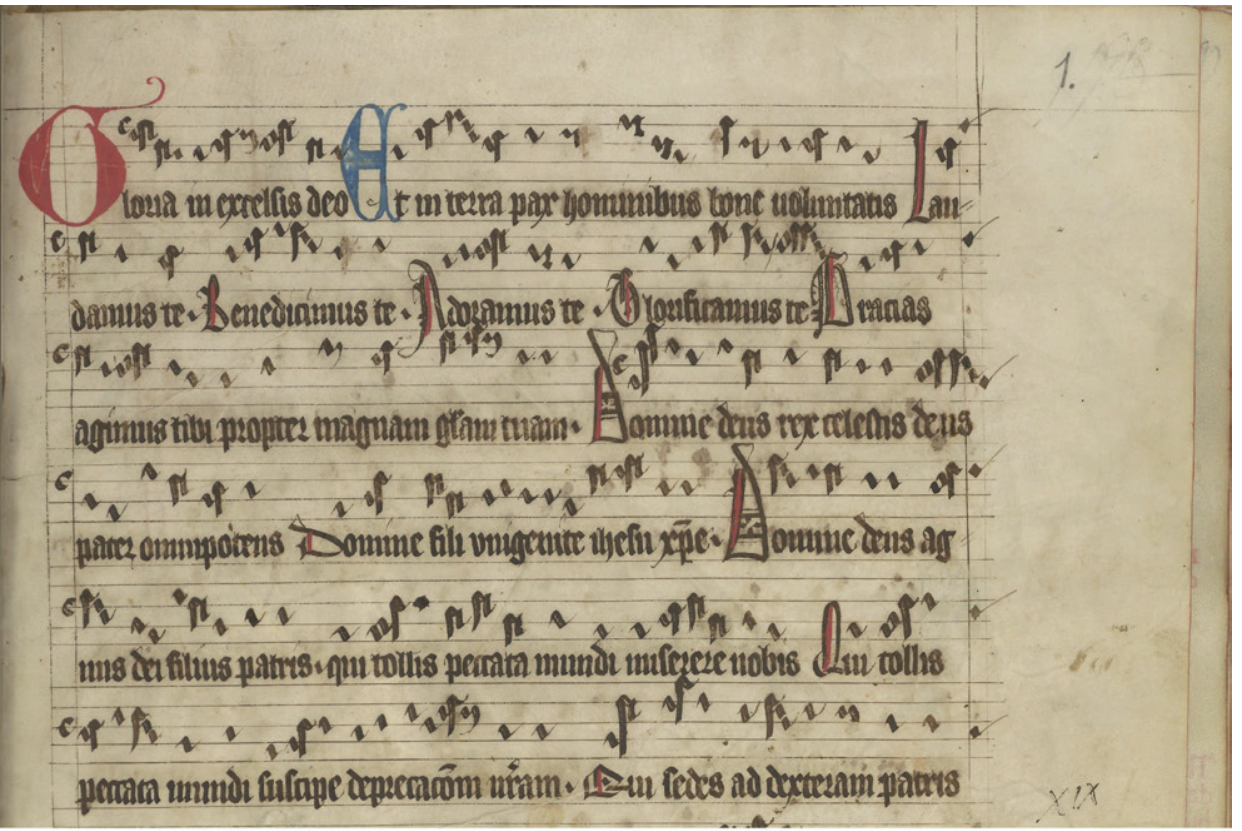

Il. 2. Warszawa, Biblioteka Narodowa, rkps I2497 IV, f. Ir

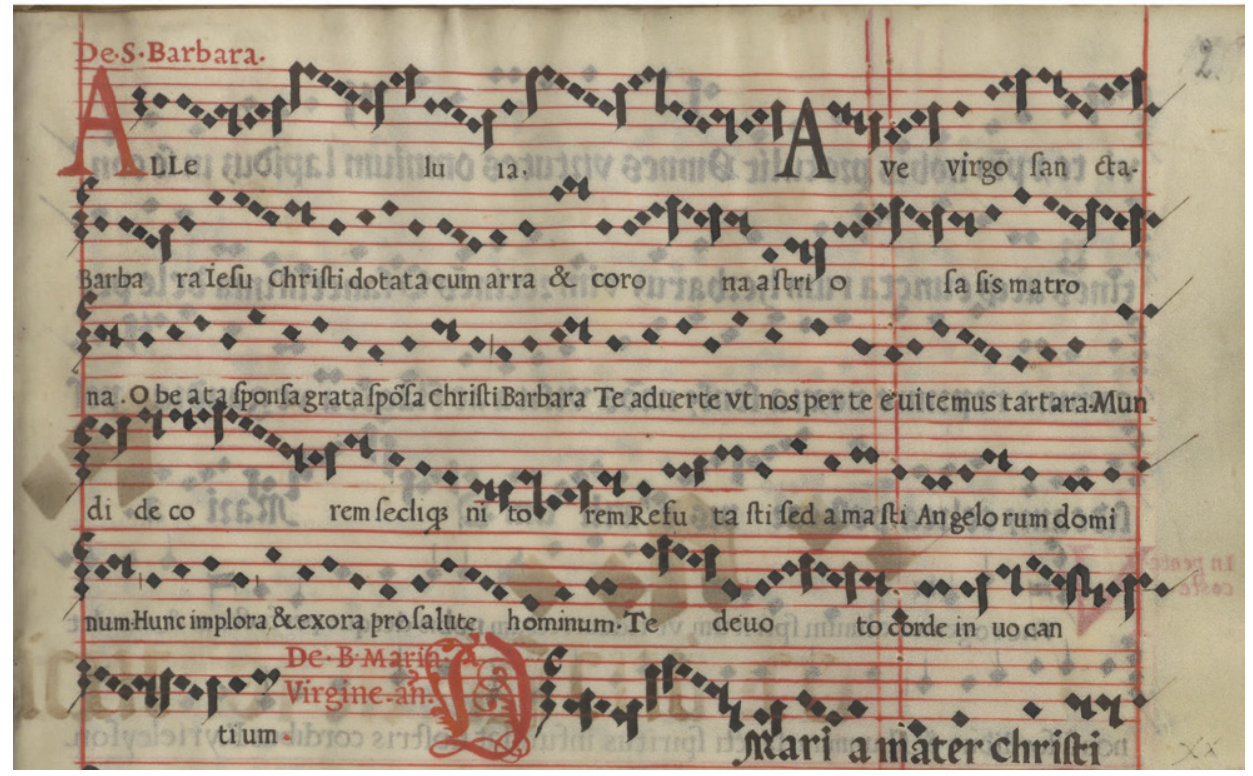

Il. 3. Warszawa, Biblioteka Narodowa, rkps I2497 IV, f. 2r 


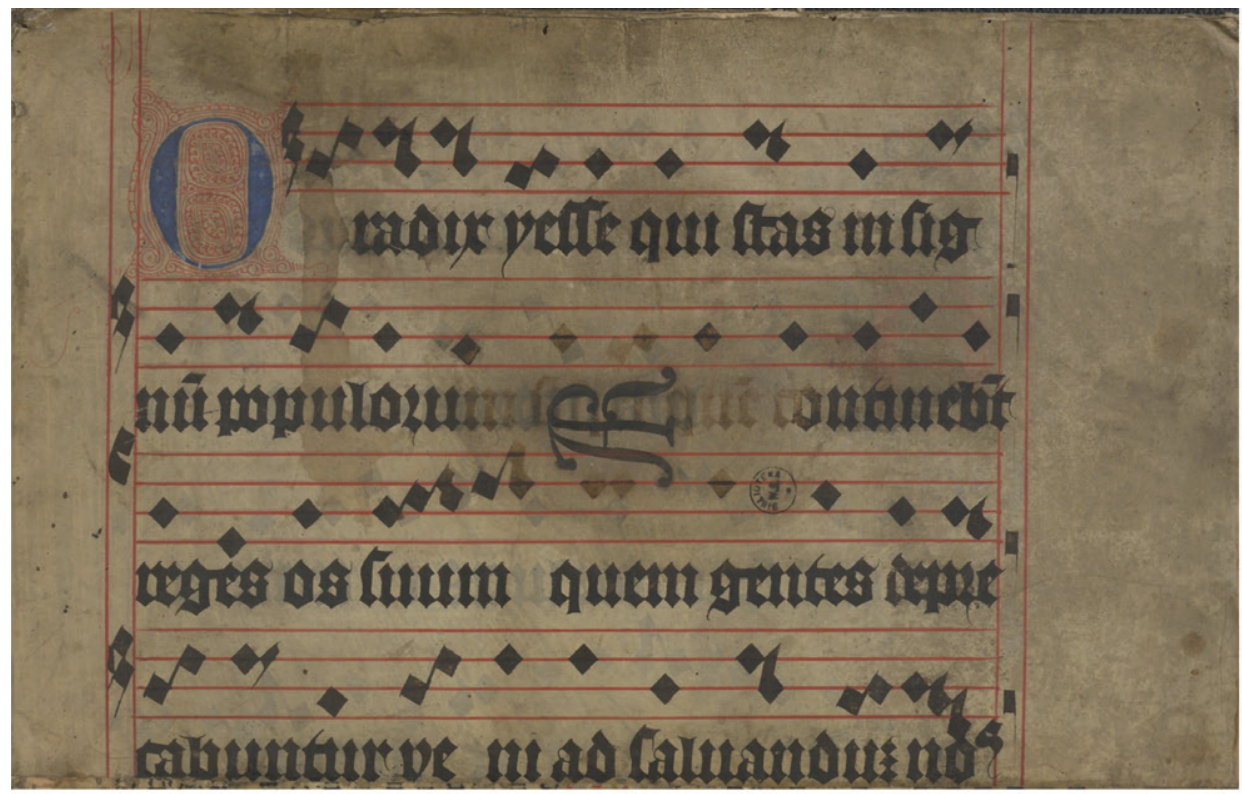

Il. 4. Warszawa, Biblioteka Narodowa, rkps I2497 IV, oprawa

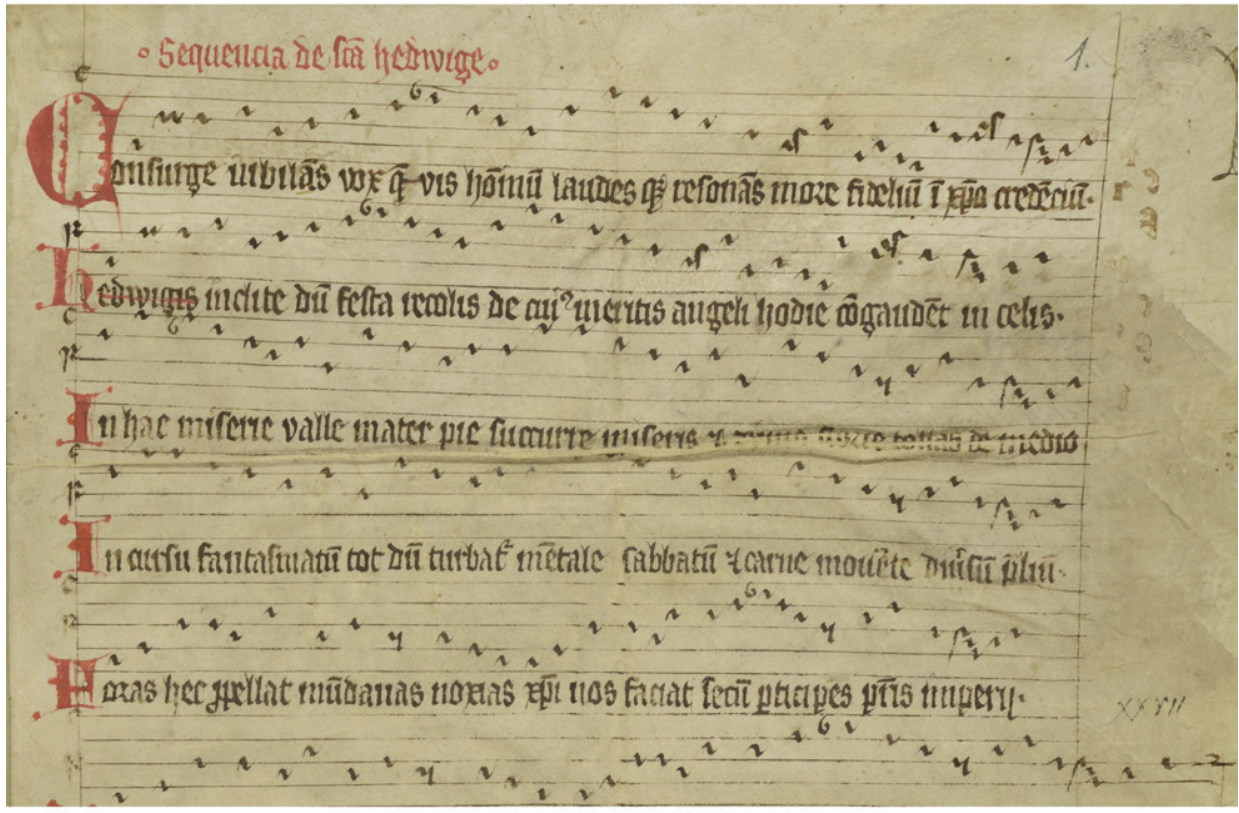

Il. 5. Warszawa, Biblioteka Narodowa, rkps 2498 IV, f. Ir 


\section{GRADUAE PL-WN I2496 IV}

Pomimo rozbieżności opinii dotychczasowych badaczy w kwestii czasu i miejsca pochodzenia graduału PL-Wn I2496 IV, wszyscy zgodni są co do cysterskiej proweniencji księgi. Rzeczywiście, dzięki pewnej swoistości cysterskich ksiąg liturgicznych zarówno pod względem ich struktury, zawartości liturgicznej (kalendarz liturgiczny, repertuar) jak też cech paleograficznych i zdobnictwa, trudno o wątpliwości, iż graduał PL-Wn I2496 IV należy do spuścizny tego zakonu.

O cysterskim pochodzeniu księgi PL-Wn 2496 IV świadczą ${ }^{17}$ :

- umieszczenie formularzy ku czci świętych z okresu Bożego Narodzenia w części de sanctis,

- wybór śpiewów Alleluja na niedzielę i święta ${ }^{\mathrm{r}}$,

- noty wstępne przed poszczególnymi cyklami mszalnymi w Kyriale (np. „Festis quibus laboramus et dominicis diebus” przed drugą mszą w PL-Wn I2496 IV, f. 85v),

- obecność działu Kyriale ad libitum na samym końcu rękopisu - co ważne, wyraźnie oddzielonego od Kyriale zasadniczego (pomiędzy nimi są hymny i antyfony), w którym znajdują się dodatkowe śpiewy ordinarium missae nie ujęte w cykle mszalne ${ }^{19}$,

- włączenie do graduału na końcu księgi hymnów ad tertiam przeznaczonych na początek mszy konwentualnej wraz z grupą antyfon (graduał PL-Wn I2496 IV zawiera dziesięć hymnów i czterdzieści cztery antyfony), co jest na ogół nietypowe dla graduałów, spotykane natomiast w księgach cysterskich ${ }^{20}$,

- notacja muzyczna (cysterska notacja w grafii gotyckiej),

- kalendarz liturgiczny (np. cysters św. Wilhelm z Bourges, św. Edmund biskup i wyznawca ${ }^{21}$, z kolei w dopisach św. Ludgarda - cysterka flamandzka).

I7 Układ graduału PL-Wn I2496 IV: proprium de tempore (święci z okresu Bożego Narodzenia są w części de sanctis), proprium de sanctis (od św. Szczepana do św. Tomasza apostoła), msze wotywne, Kyriale (Asperges me i trzy cykle mszalne), dziesięć hymnów śpiewanych w czasie tercji (na początku Mszy św. konwentualnej), czterdzieści cztery antyfony, Kyriale ad libitum, sześć sekwencji na końcu dopisane w okresie znacznie późniejszym; formularze Commune sanctorum dopisywano na marginesach później.

I8 Według Jerzego Pikulika wybór śpiewów Alleluja w graduale PL-Wn I2496 IV jest zgodny z listą tych śpiewów przyjętą przez tzw. Codex normalis obowiązujący od ok. II90 r. w całym zakonie cysterskim, zob.: Nad ztoto droższe. Skarby Biblioteki Narodowej, red. Halina Tchórzewska-Kabata, Warszawa 2000, s. 8.

I9 Dodatkowe kompozycje ordinarium missae (ad libitum) występują w licznych graduałach cysterskich, choć obecność tego działu w księdze nie stanowi reguły dla wszystkich źródeł cysterskich - dotyczy to zarówno rękopisów zachodnich, jak i tych przechowywanych w Polsce, zob.: Tadeusz Maciejewski, „Kyriale cysterskie w najstarszych rękopisach polskich: XIII i XIV wiek”, w: Musica Medii Aevi, red. Jerzy Morawski, t. 3, Kraków 1969, s. 63.

20 Oto kilka innych przykładów: PL-WRu I F 4I4, PL-WRu I F 4I5, PL-WRu I F 4I2, D-Mbs: Clm 0254I.

2I Cystersi przyczynili się do szerzenia kultu św. Edmunda w Europie (czczony głównie we Francji i Anglii). O kulcie św. Edmunda zob.: Krystyna Kuźmak, „Edmund z Abingdon”, w: Encyklopedia Katolicka, red. Romuald Łukaszyk, Ludomir Bieńkowski, Feliks Gryglewicz, t. 4, Lublin 1989, szp. 66I-662; Franciszek Wolnik, Liturgia ślaskich cystersów w średniowieczu, Opole 2002, s. 260-26I. 
Ponadto, w graduale PL-Wn I2496 występuje odmienne od watykańskiego zakończenie Credo, charakterystyczne - według ustaleń Tadeusza Maciejewskiego dla źródeł cysterskich ${ }^{22}$.

wariant cysterski: et vitam futuri saeculi amen wariant watykański:

et vitam venturi saeculi amen

W świetle badań Tadeusza Maciejewskiego nad Kyriale cysterskim graduał PL-Wn I2496 IV wydaje się wykazywać związek z grupą rękopisów śląskich ${ }^{23}$. Zasadnicza część Kyriale PL-Wn I2496 obejmuje trzy msze. Choć jest to charakterystyczną cechą większości najstarszych rękopisów cysterskich, spośród trzynasto- i czternastowiecznych rękopisów od dawna przechowywanych w Polsce trzy msze zawierają tylko kodeksy śląskie, podczas gdy pelplińskie i paradyski tylko dwie z nich ${ }^{24}$. Pomimo stosowania tych samych cykli ordinarium missae w źródłach cysterskich, śpiewy te odróżniają się własnymi wariantami melodycznymi, a poszczególne msze notowane są w różnej kolejności - pod tym względem graduał PL-Wn I2496 zgodny jest z tradycją śląską (wszystkie badane przez Maciejewskiego rękopisy śląskie zachowują identyczną kolejność poszczególnych mszy) ${ }^{25}$. Wspólną cechą graduału PL-Wn I2496 i cysterskich ksiąg śląskich, odróżniającą je zarówno od rękopisów zachodnich ${ }^{26}$ jak też od przechowywanych w Polsce graduałów pelplińskich (PL-PE II9, PL-PE Li3, PL-PE L2I) i paradyskiego (PL-PAsd 69), jest bogactwo znaków likwescentnych. Tak na przykład Agnus z trzeciej mszy w większości rękopisów śląskich jak też w graduale PL-Wn I2496 rozpoczyna się likwescentnym torculus; w tejże kompozycji neuma likwescentna łączy poszczególne sylaby wyrazów tollis i mundi (clivis likwescentna) ${ }^{27}$. Żaden z nieśląskich rękopisów nie notuje w tym miejscu (ani w innych w tym śpiewie) znaków likwescentnych. Co ciekawe, w PL-Wn I2496 IV (f. 87v), podobnie jak w kilku graduałach lubiąskich - PL-WRu I F 4I5 (f. I87v), PL-WRu I F 4I2 (f. II3v), PL-WRu I F 4I3 (f. I64v) - formuła melodyczna na ostatniej sylabie słowa „peccata” rozszerzona jest o jeden dźwięk dostawiony w unisono do pes subbipunctum (w PL-Wn I2496 oraz PL-WRu I F 413 zanotowany jest poprzez oriscus, natomiast w PL-WRu I F 4I5 i PL-WRu I F $4 \mathrm{I} 2$ za pomocą virgi) ${ }^{28}$. Poza tym, w graduale PL-Wn I2496 pojawiają się warianty niektórych formuł melodycznych charakterystyczne tylko dla rękopisów śląskich, tak np. w Agnus z drugiej mszy nad drugą syla-

T. Maciejewski, „Kyriale cysterskie”, s. 74

Graduał PL-Wn I2496 nie został uwzględniony przez Maciejewskiego.

T. Maciejewski, „Kyriale cysterskie”, s. 63-66.

Ibid., s. 65.

Chodzi tu o rękopisy zachodnie uwzględnione w badaniach Tadeusza Maciejewskiego, zob.: ibid., s. 63-64.

Np. PL-WRu I F 4I5, f. I87v; PL-WRu I F 4I3, f. I64v.

Maciejewski błędnie notuje tę formułę w przypadku PL-WRu I F 4I2 - podaje dźwięk niższy po pes subbipunctum, jak też nie zauważa likwescencji dla słowa „mundi”, zob.: T. Maciejewski, „Kyriale cysterskie", s. 69. 
bą wyrazu „agnus” w PL-Wn I2496 (f. 87r) i większości graduałów śląskich występuje pojedynczy dźwięk $(f)$, podczas gdy w pozostałych rękopisach (również obcych) jest tu neuma clivis $(f-e)^{29}$.

Także rubryki występujące w zasadniczym Kyriale (wstępne noty przed poszczególnymi cyklami mszalnymi) najbardziej zbliżone są do śląskich ${ }^{30}$.

Jak wspomniano, graduał PL-Wn 12496 zawiera także dział Kyriale ad libitum. Wśród badanych przez Maciejewskiego rękopisów ten uzupełniający zestaw śpiewów ordinarium missae występuje tylko w czterech źródłach (z dziesięciu); wszystkie pochodzą ze skryptoriów śląskich (PL-WRu I F 4I2, PL-WRu I F 4I4, PL-WRu I F 4I5, PL-WRu I F 4I7). Pomimo charakterystycznej dla Kyriale ad libitum niejednolitości repertuaru ${ }^{31}$, w graduale PL-Wn I2496 IV tę grupę śpiewów tworzy ten sam zestaw kompozycji co w lubiąskim graduale PL-WRu I F 4I4 dodatkowo wzbogacony o cztery inne śpiewy (dwa Kyrie, Sanctus i Agnus). O pokrewieństwie pomiędzy PL-Wn I2496 a rękopisami śląskimi świadczyć mogą także dwie melodie zidentyfikowane do tej pory tylko w rękopisach śląskich - Sanctus ${ }^{32}$ (PL-Wn I2496, f. 94r; PL-WRu I F 4I2, f. I33v; PL-WRu I F 4I7, f. 5) oraz Kyrie ${ }^{33}$ (PL-Wn I2496, f. 95r; PL-WRu I F 4I4, f. I27; PL-WRu I F 4I5 f. I85; PL-WRu I F 4I7, f. I).

W nurcie tradycji śląskiej graduał PL-Wn I2496 IV mieści się także pod względem notacji muzycznej, na co wskazała już Janka Szendrei ${ }^{34}$. Pismo muzyczne stanowi tu notacja cysterska w grafii gotyckiej, bardzo charakterystyczna dla trzynastowiecznych źródeł śląskich $-\mathrm{z}$ właściwą dla tego regionu techniką pisania niektórych neum (il. I ${ }^{35}$. System notacyjny graduału PL-Wn I2496 IV tworzą typowe dla notacji cysterskiej elementy, jak kolorowana liniatura (czerwona linia dla $F$, zółta dla $c$, pozostałe zielone), kustosz przypominający cyfrę „2”, b rotundum i quadratum, trzy literowe klucze (c, f, g) oraz zestaw znaków neumatycznych zasadniczo zachowujących ich francuską strukturę charakterystyczną dla pierwotnej notacji cysterskiej, ale z pewnymi wpływami regionalnymi w poszczególnych neumach - np. w scandicus kolejne elementy neumatyczne nie są ustawione już pionowo, choć postępują w górę jeszcze dosyć stromo, z kolei w neumie porrectus główka trzeciego dźwięku zdarza się być notowana

29 Por.: T. Maciejewski, „Kyriale cysterskie”, s. 71; PL-Wn I2496, k. 87r. Pewne zbieżności PL-Wn I2496 z rękopisami śląskimi można także obserwować w grupowaniu neumatycznym niektórych dłuższych przebiegów melodycznych, np. w Sanctus z drugiej mszy - melodia nad zwrotem „osanna in excelsis” (PL-Wn I2496, f. 87r), ibid., s. 7I.

30 Por.: ibid., s. 77-79.

3I Ibid., s. 77-79.

32 Melodia tej kompozycji jest określona przez Maciejewskiego jako niezidentyfikowana, zob.: ibid., s. 84 .

33 Ibid., s. 82.

34 J. Szendrei, „Notacja liniowa”, s. 194.

35 Bardzo charakterystyczna pod tym względem jest neuma pes, której dolny element w skryptoriach śląskich jest kreślony grubszą poziomą kreską, podczas gdy w źródłach zachodnich raczej jest stosowane metzeńskie punctum z cienką kreseczką wstępującą po jego lewej stronie. Charakterystyczna jest także spiczasta forma clivis z wyraźnie wydłużoną lewą laseczką. 
zarówno obrócona w lewo, zgodnie z francuską strukturą tej neumy, jak też w prawo, co jest cechą porrectus metzeńskiego. Tak jak w przypadku wielu innych źródeł śląskich z XIII w., notacja PL-Wn I2496 IV z jednej strony zasadniczo zachowuje ductus francuski, będący integralnym elementem muzycznego pisma cysterskiego, z drugiej zaś zawiera obcy dla pierwotnej notacji cysterskiej ornamentacyjny element neumatyczny pochodzący z notacji niemieckiej - oriscus (np., PL-Wn I2496 IV, f. 23r, na końcu piątego systemu).

Pismo muzyczne stanowi istotną przesłankę przemawiającą nie tylko za cysterskim pochodzeniem rękopisu, lecz także jego śląską proweniencją. Przy tym analiza paleograficzna graduału w kontekście licznej grupy źródeł pochodzących z cysterskich skryptoriów na Śląsku pozwala na dość precyzyjną datację kodeksu. Pod względem struktury poszczególnych neum (form będących skutkiem wpływu pisma regionalnego) jak i stylu zapisu (wskazującego na określone stadium ewolucji zmierzającej ku pismu kodeksowemu) notacja muzyczna graduału PL-Wn I2496 IV niewątpliwie mieści się $\mathrm{w}$ grupie źródeł pochodzących z drugiego trzydziestolecia XIII w. (zob. tab. I, por. z PL-WRu I F 4I4 i PL-WRu I F 4I $\mathrm{I}^{86}$ ). Z jednej strony skryptor nie jest już tak zachowawczy względem struktury niektórych neum, jak też w samej technice pisania - zanikają bowiem powszechne na początku stulecia zmiękczenia i zaokrąglenia w miejscu zmiany kierunku pióra (tab. I, por. z PL-WRu I F 403 z ok. I225 r. $)^{37}$, z drugiej zaś, nie nastąpiła jeszcze wyraźna zmiana w prowadzeniu pióra zmierzająca do artystycznie stylizowanego pisma kodeksowego z główkami poszczególnych nut w kształcie dokładnego, niezaokrąglonego rombu (tab. I, por. z PL-WRu I F 4II z ok. I260-70) ${ }^{38}$. Choć analiza paleograficzna wyraźnie wskazuje na pokrewieństwo pisma muzycznego rękopisu PL-Wn I2496 IV z notacją ksiąg datowanych na lata czterdzieste i pięćdziesiąte, nie daje się zidentyfikować tej samej ręki w żadnym graduale czy antyfonarzu powstałym w tym okresie w cysterskim skryptorium na Śląsku. Na podstawie samej notacji muzycznej rękopis można zatem datować na okres pomiędzy I240 a I260 rokiem.

36 PL-WRu I F 4I4, lata czterdzieste XIII w.; PL-WRu I F 4I8, ok. I245 r.; por. także PL-WRu I F 402, pomiędzy rokiem I235 a I253. Datacja za: Konstanty Klemens Jażdżewski, Lubiąz. Losy i kultura umystowa ślaskiego opactwa cystersów (II63-I642), Wrocław 1992, s. I49; Andrzej Wałkówski, Skryptoria cystersów filiacji portyjskiej na Ślasku do końca XIII w., Zielona Góra-Wrocław I996, s. $236-237$.

37 Por. także: PL-WRu I F 399, przełom XII/XIII w.; PL-WRu I F 4I5, ok. I220 roku. Datacja za: K.K. Jażdżewski, Lubiąż, s. I49; A. Wałkówski, Skryptoria cystersów, s. 227.

38 Bliskie pismu kodeksowemu są notacje PL-WRu I F 4II z ok. I260-70 i PL-WRu I F 4I2 z ok. I265 r., natomiast typowe stylizowane pismo występuje w PL-WRu I F 40I z ok. I295 r. oraz w późniejszym o około trzydzieści lat PL-WRu I F 4I3. Datacja za: K.K. Jażdżewski, Lubiąż, s. I49; A. Wałkówski, Skryptoria cystersów, s. $25 \mathrm{I}$. 
Tab. I.

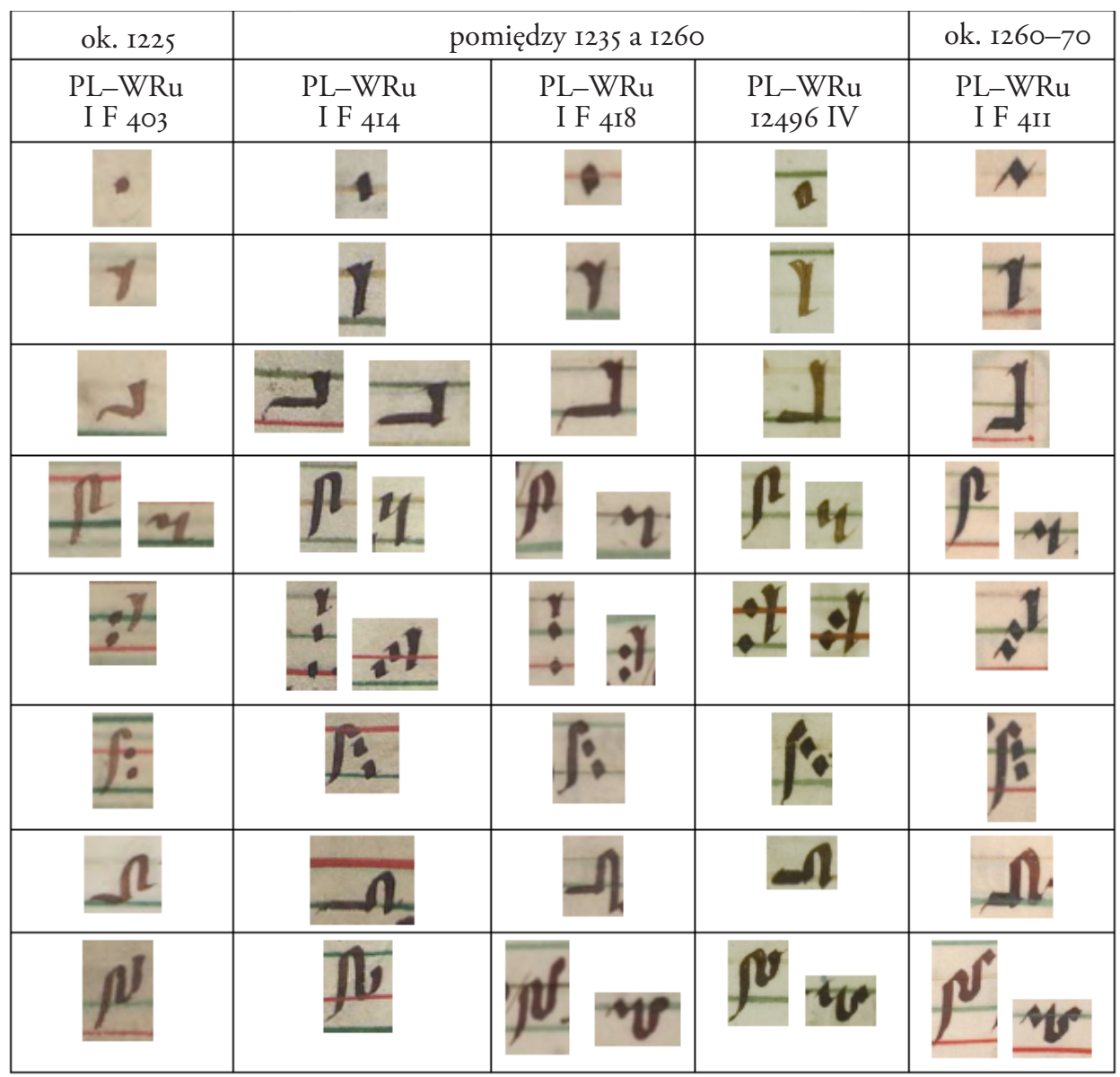

Zastosowanie kryterium liturgicznego pozwala na dalsze zawężenie zakresu czasowego. Obecność w graduale św. Edmunda, biskupa Canterbury, w proprium de sanctis (f. 82: „Ethmundi epi omnia Nicolai”) wyznacza terminus post quem na rok I247, w którym św. Edmund został kanonizowany, i od tegoż roku czczony był w całym zakonie cysterskim ${ }^{39}$. Z kolei terminus ante quem podyktowany jest brakiem niektórych

39 Statuta capitulorum generalium ordinis Cisterciensis ab anno III6 ad annum I786, red. Josephus-Maria Canivez, Löwen 1934 (= Bibliothèque de la Revue d'histoire ecclésiastique 2), s. 3I5, c. 2: „Sexto decimo kalendas decembris festum beati Edmundi per Ordinem universum fiat, et de eo per omnia sicut de beato Nicolao, excepto quod cellectae a domino Papa factae per totum Ordinem et conversi laborabunt", cyt. za: F. Wolnik, Liturgia, s. 26I, p. 229. Co ciekawe, św. Edmunda nie ma jeszcze w lubiąskim graduale PL-WRu I F 4I4 - został dopisany ręką współczesną na marginesie f. Iogr - co by oznaczało, iż księga datowana przez Jażdżewskiego na lata czterdzieste (w literaturze najczęściej na ok. I250 r.) musiała powstać przed rokiem I247, zob.: K.K. Jażdżewski, Lubiąż, s. I49. 
świętych, których cystersi darzyli szczególnym kultem. W części oryginalnej brakuje kilku świętych kanonizowanych w latach pięćdziesiątych XIII w., natomiast formularze ku ich czci zostały dopisane na marginesach rękopisu w nieco późniejszym czasie: św. Stanisław (kanonizacja w I253 r., f. 69v) ${ }^{40}$, św. Piotr Męczennik (tj. Piotr z Werony, kanonizacja w I253 r.), św. Dominik (czczony przez cystersów od I255 r.) $4^{41}$, jak też św. Urszula i Towarzyszki („XI Milium Virginum”), które zgodnie z postanowieniem kapituły w Cîteaux od I260 r. czczono w całym zakonie cysterskim (cystersi należą do jednych z największych czcicieli i propagatorów kultu relikwii Kolońskich Męczenniczek) ${ }^{42}$. Niewątpliwie do końca lat pięćdziesiątych rękopis musiał zostać sporządzony. Biorąc pod uwagę obecność żywej tradycji kultu św. Stanisława w środowisku cystersów śląskich, co więcej, istnienie śladów kultu krakowskiego biskupa i męczennika u cystersów śląskich jeszcze przed kanonizacją biskupa, jak też polecenie kapituły generalnej cystersów w I255 r. ${ }^{43}$ czczenia św. Stanisława kultem dwunastolekcyjnym z dwiema mszami świętymi ${ }^{44}$, wydaje się, że za terminus ante quem można przyjąć rok kanonizacji świętego I253. Tym samym czas powstania rękopisu zawężamy do okresu pomiędzy I247 a I253 rokiem. Tak więc badania nad oryginalną częścią graduału PL-Wn I2496 wskazują na sporządzenie księgi w cysterskim skryptorium na Śląsku ok. I250 roku.

Dalsze porównania graduału PL-Wn I2496 z grupą rękopisów muzycznych (graduałów i antyfonarzy) z lat czterdziestych i pięćdziesiątych XIII w. pochodzących ze śląskich skryptoriów cysterskich ujawniły związek kodeksu PL-Wn 12496 z graduałem lubiąskim PL-WRu I F 4I4 poprzez dopisy późniejsze45. Tą samą ręką, która wpisała na kilku kartach graduału PL-WRu I F 4I4 (I23r-I26) sześć sekwencji (il. 6), też same kompozycje dopisane zostały na czterech ostatnich kartach badanego kodeksu (Mittit ad Virginem, Mane prima sabbati, Ave praeclara maris stella, Laetabundus exsultet, Ave cella novae legis, Gaude mater luminis, il. 7). Co więcej, w obu rękopisach występują także dopisy marginalne jeszcze z XIII w., które również wyszły spod jednej ręki (dopisy zielonym atramentem, np. PL-Wn I2496 IV, f. 68r; PL-WRu I F 4I4, f. 9Ir).

Formularz ku czci św. Stanisława został dopisany także w nieco starszym graduale lubiąskim PL-WRu I F 4I4 (f. 92v).

4I F. Wolnik, Liturgia, s. 245.

42 Janusz Nowiński, „Cystersi propagatorami kultu relikwii św. Urszuli i jej Towarzyszek (Undecim Milium Virginum) - wybrane przykłady”, Saeculum Christianum 2I (20I4), s. 6I-72.

43 F. Wolnik, Liturgia, s. 436, zob. także przyp. I7I.

44 Według kalendarzy cystersów śląskich św. Stanisław miał być czczony w najwyższym rycie w dniu 8 maja.

$45 \mathrm{~W}$ postaci zdigitalizowanej rękopis jest dostępny w Bibliotece Cyfrowej Uniwersytetu Wrocławskiego, https://www.bibliotekacyfrowa.pl/dlibra/publication/18067/, dostęp 3I VIII 2020. 


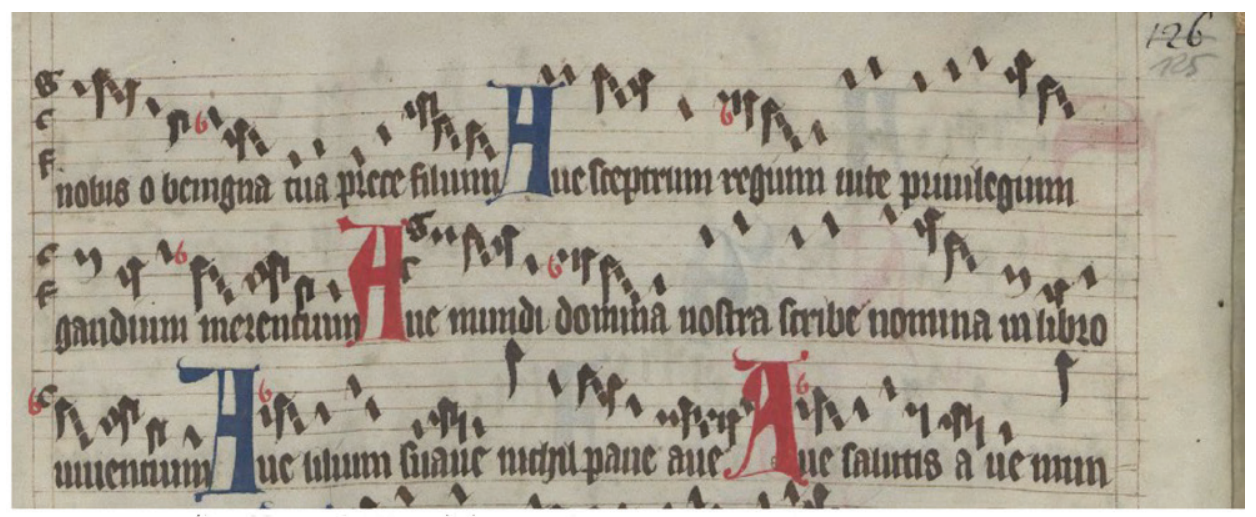

Il. 6. Wrocław, Biblioteka Uniwersytecka, Oddział Rękopisów, Ms. I F 4I4, f. I25r

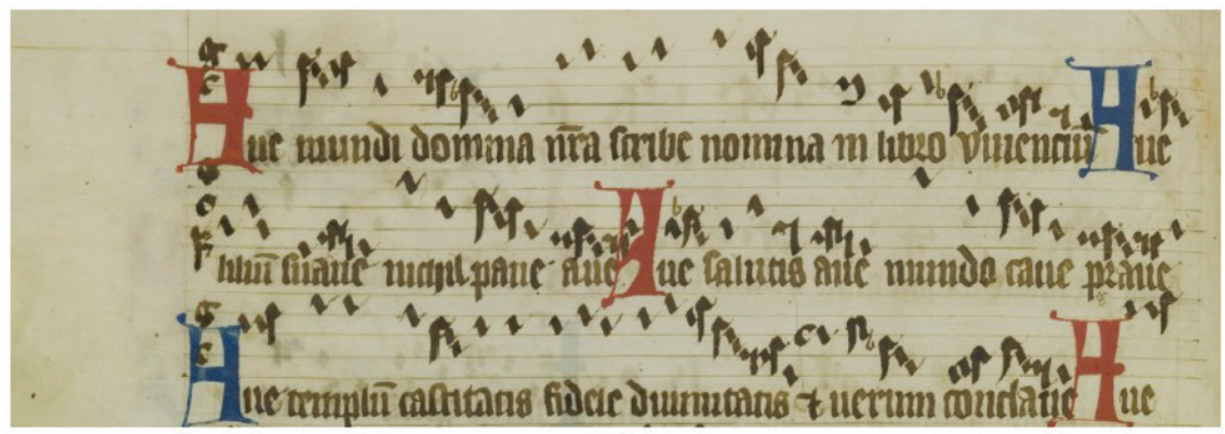

Il. 7. Warszawa, Biblioteka Narodowa, rkps I2496 IV, f. 98v

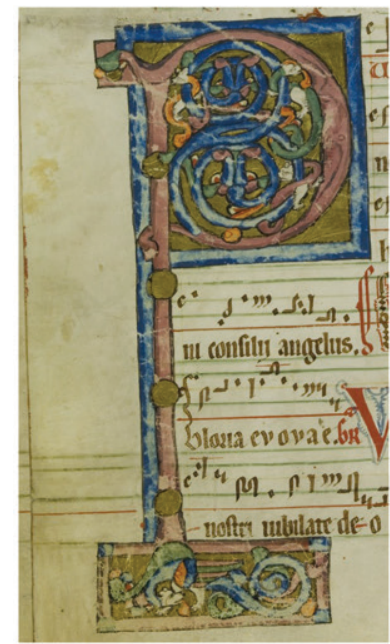

Il. 8. Warszawa, Biblioteka

Narodowa, rkps 12496 IV, f. $7 \mathrm{~V}$

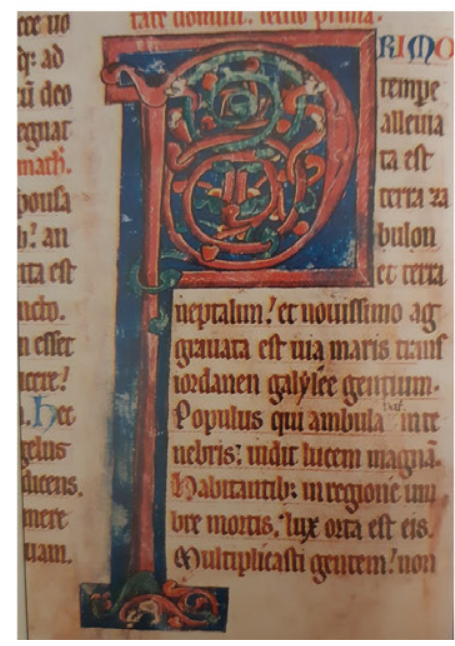

Il. 9. Wrocław, Biblioteka Uniwersytecka, Oddział Rękopisów, Ms. I F 663 , t. I, f. 45 r

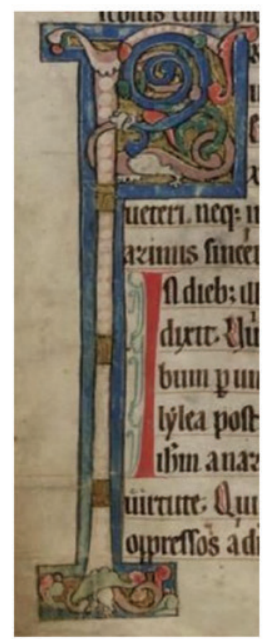

Il. ı. Wrocław, Biblioteka Uniwersytecka, Oddział Rękopisów, Ms. I Q 255, f. 37v 


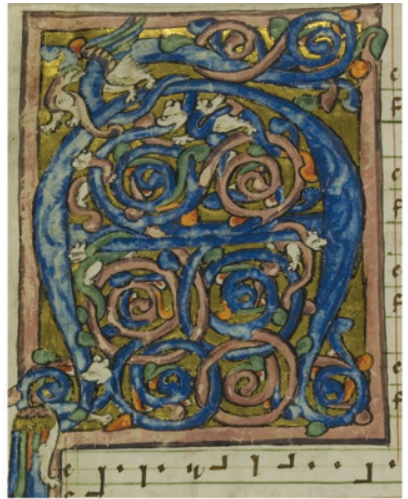

Il. II. Warszawa, Biblioteka Narodowa, rkps I2496 IV, f. IV

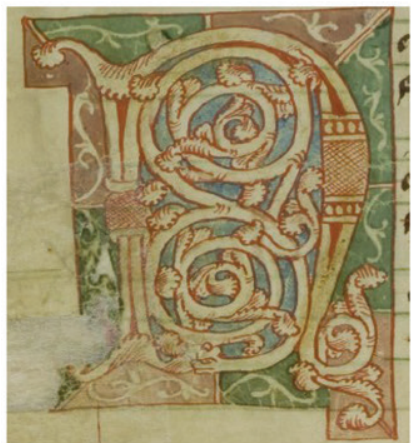

Il. I3. Warszawa, Biblioteka Narodowa, rkps I2496 IV, f. 73v

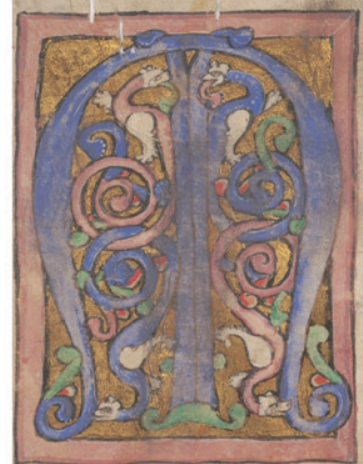

Il. I2. Wrocław, Biblioteka Uniwersytecka, Oddział Rękopisów, Ms. I F 663, t. 2, f. Iv

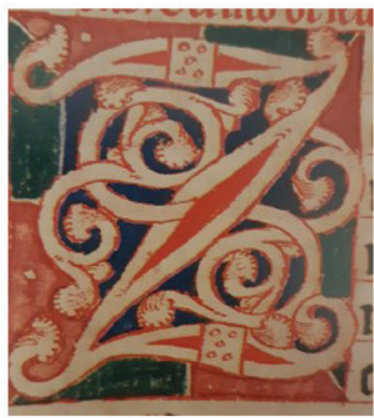

Il. I4. Wrocław, Biblioteka Uniwersytecka, Oddział Rękopisów, Ms. I F 663, t. I, f. I4Iv

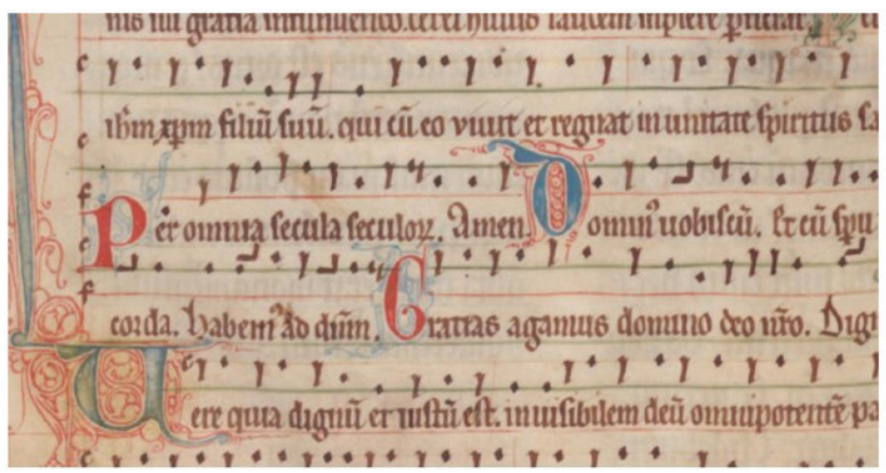

Il. I5. Wrocław, Biblioteka Uniwersytecka, Oddział Rękopisów, Ms. I F 46o, f. 42v

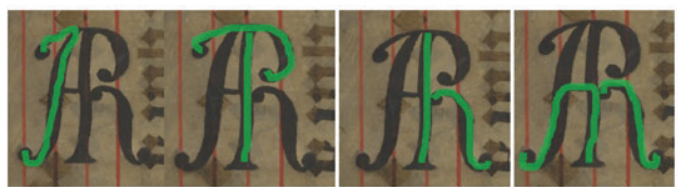

Il. I6. Warszawa, Biblioteka Narodowa, inicjały z oprawy rękopisu I2497 IV 
Ustalenie związku graduału PL-Wn I2496 ze skryptorium lubiąskim wskazało na konieczność podjęcia dalszych badań, obejmujących tym razem nie tylko księgi ściśle muzyczne, ale wszystkie pozostałe księgi używane podczas liturgii powstałe w skryptorium lubiąskim w podobnym okresie - są nimi dwa lekcjonarze PL-WRu I F 46046 i PL-WRu I Q $255^{47}$ oraz trzyczęściowy homiliarz PL-WRu I F $663^{48}$. Wszystkie trzy rękopisy datowane są w literaturze na połowę XIII w. ${ }^{49}$. W dwóch z tych kodeksów - PL-WRu I Q 255 i PL-WRu I F 663 - autorem ich ornamentyki, zdaniem Dariusza Tabora oraz Konstantego Jażdżewskiego, jest ten sam malarz ${ }^{50}$. Co ciekawe, zdobienia inicjałów tych dwóch rękopisów, szczególnie zaś homiliarza, uderzająco przypominają zdobienia graduału PL-Wn I2496 IV (il. 8-I2). Podobieństwa dotyczą zarówno kolorystyki jak też ornamentyki inicjałów. We wszystkich trzech kodeksach użyto podobnych barw z przewagą różnych odcieni czerwieni, a także zieleni i błękitu; litery ujęto w ramki i usytuowano na barwnych, czasem złotych tłach. Niezwykle podobne są kształty motywów - wolut, smoków, półlistków - zastosowane do zdobienia inicjałów wszystkich trzech rękopisów. Szczególnie charakterystycznym motywem zdobiącym jest smok, obsesyjnie, jak się wydaje, stosowany przez iluminatora (w graduale PL-Wn I2496 IV pojawia się niemal we wszystkich zdobionych inicjałach). Ciała smoków wplatane są w strukturę ornamentalną inicjałów, spiralne nici nieraz są jakby wypluwane $\mathrm{z}$ ich paszczy. Kształt smoczej głowy jest zasadniczo identyczny we wszystkich trzech księgach. W graduale PL-Wn I2496 IV występuje także inicjał (f. 73v), w którym półlistki nie są wypełnione barwą, lecz szrafowane - tego typu inicjały występują także w homiliarzu PL-WRu I F 663 (il. I3 i I4) ${ }^{\text {sI }}$. Wydaje się, iż zdobienia graduału PL-Wn I2496 IV oraz lekcjonarza I Q 255 i homiliarza I F 663 pochodzących ze skryptorium lubiąskiego są dziełem jednego artysty, choć ostateczną ocenę w tej kwestii należy pozostawić historykom sztuki.

W obu wymienionych kodeksach lubiąskich ${ }^{52}$ Jażdżewski dostrzega także jedną rękę piszącą pismem carolino-gothica (jeszcze dość romańskie, o nielicznych łamaniach, ale już pionowe i dość ciasne) ${ }^{53}$. Do dzieł tegoż skryptora zalicza również trzeci

46 W postaci zdigitalizowanej rękopis jest dostępny w Bibliotece Cyfrowej Uniwersytetu Wrocławskiego, https://www.bibliotekacyfrowa.pl/dlibra/publication/3666I/, dostęp 3I VIII 2020.

47 Ibid., https://www.bibliotekacyfrowa.pl/dlibra/publication/I9370/, dostęp 3I VIII 2020.

48 Ibid., cz. I - https://www.bibliotekacyfrowa.pl/dlibra/publication/324II/https:/www.bibliotekacyfrowa. $\mathrm{pl} /$ dlibra/publication/3666I/, cz. 2 - https://www.bibliotekacyfrowa.pl/dlibra/publication/36482/, cz. 3 https://www.bibliotekacyfrowa.pl/dlibra/publication/36483/, dostęp 3I VIII 2020.

49 K.K. Jażdżewski, Lubiąż, s. I49; Dariusz Tabor, Iluminacje cysterskich kodeksów ślaskich XIII wieku, Kraków 2004, s. I38-I39; A. Wałkówski, Skryptoria cystersów.

50 Jażdżewski zalicza do tej grupy także Biblię Henrykowską, jednak Tabor sprzeciwia się tej tezie, zob.: D. Tabor, Iluminacje, s. 74, K.K. Jażdżewski, Lubiąż, s. 202.

5I O ornamentacji rękopisów PL-WRu I F 663 oraz PL-WRu I Q 225, jak też o genezie tego typu zdobnictwa pisze Dariusz Tabor, zob.: D. Tabor, Iluminacje, s. 44-46.

52 Powstałych w Lubiążu, bowiem lekcjonarz był używany w klasztorze kamienickim.

53 K.K. Jażdżewski, Lubiąz, s. 188. 
ze wspomnianych nieco wcześniej kodeksów powstałych w skryptorium lubiąskim ok. I250 r. - lekcjonarz PL-WRu I F 460. Identyfikację jednej ręki w odniesieniu do tych trzech źródeł potwierdza także Andrzej Wałkówski. Według jego typologii, oznaczającej poszczególne ręce skryptorium lubiąskiego kolejnymi literami alfabetu, jest to ręka „Y”, datowana na okres pomiędzy rokiem I235 a I25354. Tej ręce obaj badacze przypisują łącznie tylko trzy wspomniane rękopisy (lekcjonarze PL-WRu I Q 255 i PL-WRu I F 460 oraz homiliarz PL-WRu I F 663). Jak się wydaje, do tej grupy należy dołączyć także nasz graduał. Pismo graduału jest szczególnie zbliżone do pisma lekcjonarza PL-WRu I Q 255, które Jażdżewski charakteryzuje jako bardziej wyrafinowany wariant pisma ręki „Y” - „więcej kaligraficzne”, z trzonkami liter bardziej prostymi, równymi, stopkami (lekko ukośnymi) ledwo zaznaczonymi i nierozwidlanymi laskami"ss. Poniższa tabela zawiera przykłady wyrazów zapisanych w lekcjonarzu PL-WRu I Q 255 oraz graduale PL-Wn I2496 IV, natomiast bardziej dokładną charakterystykę pisma (PL-WRu I Q 255) przedstawia Jażdżewski w pracy poświęconej lubiąskiemu opactwu ${ }^{56}$.

Tab. 2 .

\begin{tabular}{|c|c|}
\hline PL-WRu I Q 255 & PL-Wn I2496 IV \\
\hline angelits & angelus. \\
\hline babiant & babutant \\
\hline teftament & teftamenta \\
\hline Cácriticua & factuficua \\
\hline deni. & deus \\
\hline tulls & tatos \\
\hline meos & meus \\
\hline cedamaut & Illuxt \\
\hline autem & ante \\
\hline
\end{tabular}

54 A. Wałkówski, Skryptoria cystersów, s. 239.

55 K.K. Jażdżewski, Lubiąż, s. 200.

56 Ibid., s. I88. 
W lekcjonarzach spisanych ręką „, $Y$ ” występują także znaki neumatyczne dodane nad tekstami listów (PL-WRu I Q 255) czy ewangelii (PL-WRu I F 460)57. Są to jednak jedynie pojedyncze neumy nad tekstami liturgicznymi, zanotowane bez systemu liniowego i ścieśnione pomiędzy wierszami tekstu. Bardzo cenny natomiast dla badań paleograficznych okazał się wpis całej melodii Exsultet w lekcjonarzu PL-WRu I F 460 (f. 42v-44r) stanowiący jedyny przykład kompozycji zanotowanej za pomocą pełnego systemu notacyjnego - z neumami na liniach opatrzonych kluczami i kustoszem - obecny w dziełach spisanych ręką „Y” (il. I5) $)^{58}$.

Choć melodia Exsultet jest wybitnie sylabiczna, wskutek czego jej notacja pozbawiona jest jakichkolwiek złożeń neumatycznych, i do porównania mamy zaledwie kilka neum podstawowych (punctum, virga, pes, clivis, dwie formy scandicus) oraz jedną likwescentną, ta sama ręka w tekście muzycznym lekcjonarza i graduału daje się potwierdzić bez żadnych wątpliwości (por. il. I z il. I5). Poza ogólnym podobieństwem zapisów muzycznych, wynikającym z zastosowania charakterystycznego sposobu kolorowania liniatury - żółta linia dla $c$, czerwona dla $f$ oraz pozostałe zielone - jak też kustosza i kluczy literowych o tym samym kształcie, w obu przypadkach obserwować można swoiste cechy pisma muzycznego będące odbiciem określonej techniki pisania oraz indywidualnych cech charakteru pisma danego skryptora.

Najbardziej charakterystyczną cechą pisma - swego rodzaju wizytówką - jest sposób kreślenia dolnego elementu neumy pes - pozioma kreska nieco rozszerzająca się ku lewej stronie, kończąca się delikatną wznoszącą się ukośnie w prawo bardzo krótką kreseczką (zob. tab. 3, PL-Wn I2496 IV i PL-WRu I F 460). Dla porównania w innych źródłach trzynastowiecznych - zarówno starszych jak młodszych względem graduału czy lekcjonarza - bardziej typowe jest ewentualne lekkie zwężanie tej części poziomego elementu pes z pociągnięciem bardzo cienkiej, ale wyrazistej kreseczki na ukos w dół (a nie w górę) na samym jego końcu (por. PL-WRu I F 4I4, PL-WRu I F 402, PL-WRu I F 403) $)^{59}$.

57 Jerzy Morawski wymienia lekcjonarz PL-WRu I Q 255 jako przykład źródła zawierającego neumy cheironomiczne. Dopisane nad tekstami liturgicznymi neumy (bez linii) pochodzą jednak z ukształtowanego systemu liniowego. W tym czasie cystersi nie używali już notacji bezliniowej (zgodnie z postanowieniami kapituły generalnej), natomiast neumy miały na celu jedynie przypomnienie prostej, znanej wykonawcom formuły melodycznej, zob.: J. Morawski, Średniowiecze, s. 398, 44I.

58 Rękopis ów nie został uwzględniony przez Wałkówskiego w publikacji poświęconej pismu trzynastowiecznych rękopisów lubiąskich zawierających notację muzyczną, zob.: Andrzej Wałkówski, „Lubiąskie rękopisy muzyczne z XIII w. na tle badań nad skryptoriami cystersów. Nutacja diastematyczna”, Acta Universitatis Lodziensis. Folia Librorum I8 (2014), s. 9-34.

59 Por. także PL-WRu I F 402, PL-WRu I F 403. Rękopisy są dostępne w Bibliotece Cyfrowej Uniwersytetu Wrocławskiego, bibliotekacyfrowa.pl, dostęp 3I VIII 2020. 
Tab. 3 .

\begin{tabular}{|c|c|c|c|c|c|}
\hline PL-Wn I2496 IV & PL-WRu I F 460 & PL-WRu I F 399 & PL-WRu I F 4I4 & PL-WRu I F 418 & PL WRu I F 4II \\
\hline & & & & & \\
\hline
\end{tabular}

Charakterystyczna jest także prostokątna forma neumy clivis. Główka pierwszego dźwięku neumy jest notowana niemal równolegle względem drugiego elementu clivis (ewentualnie z delikatnym odchyleniem w lewo), wraz z małą kreseczką prowadzącą do drugiego elementu neumatycznego, tworząc zaokrąglone zgięcie (nawiązując tym samym do pierwotnego kształtu metzeńskiej clivis). Rozmiary pierwszego elementu clivis najczęściej przekraczają rozmiary izolowanego romboidalnego punctum - wyjątek stanowi złożenie clivis z poprzedzajacym ją punctum w unisonie. Skryptor rozpoczyna zapis znaku bardzo krótką, nieraz ledwo zauważalną wprowadzającą kreseczką (przy pierwszym elemencie neumatycznym) i kończy pociągniętą na ukos - bardzo często dość wyraźnie - kreseczką wstępującą do góry (tab. 4 - pierwsza i druga kolumna). W pozostałych źródłach pochodzących z podobnego okresu z cysterskich skryptoriów na Śląsku pierwszy element clivis (prostokątnej) jest najczęściej notowany za pomocą regularnego rombu z wyraźnie dłuższą kreseczką wprowadzającą (tab. 4, kolumny 3-5). Wyróżnia się jedynie zapis clivis w graduale I F 4I4, gdzie oba elementy neumatyczne są ustawione równolegle i połączone cieniutką ukośną kreseczką - wyraźnie dłuższą niż w PL-Wn I2496 IV i PL-WRu I F 460 (przez równoległe ustawienie elementów przypomina kształtem cyfrę „4”, zob. tab. 4, szósta kolumna).

Tab. 4 .

\begin{tabular}{|c|c|c|c|c|c|}
\hline PL-Wn I2496 IV & PL-WRu I F 460 & PL-WRu I F 4I8 & PL-WRu I F 402 & PL-WRu I F 4II & PL WRu I F 4I4 \\
\hline & & & & & \\
\hline
\end{tabular}

Także pozostałe neumy, choć nie aż tak charakterystyczne jak pes czy clivis, zdradzają rękę tego samego skryptora - punctum o kształcie zbliżonym do rombu (jeszcze nieco zaokrąglonego), często z minimalną kreseczką wprowadzającą albo też z podobną wstępującą po przeciwnej stronie rombu oraz virga z charakterystyczną główką nutową i pociągnięciem cienkiej kreseczki na końcu neumy.

Analiza paleograficzna pisma muzycznego graduału PL-Wn I2496 IV i lekcjonarza PL-WRu I F 460 (melodia Exsultet) nie pozostawia wątpliwości, iż rękopisy 
należą do spuścizny tego samego skryptora. Do dzieł tegoż kopisty należy dołączyć także lekcjonarz PL-WRu I Q 255; choć nie zawiera on pełnego systemu notacyjnego, to jednak sposób prowadzenia pióra w przypadku neumy pes - choć bez linii i nieco ścieśnionego pomiędzy wierszami - ujawnia rękę kopisty ${ }^{60}$.

Podsumowując, graduał PL-Wn I2496 uznać należy za produkt lubiąski sporządzony około I250 r. (pomiędzy rokiem I247 a I253), spisany ręką „Y” (według typologii Wałkówskiego) tak jak lekcjonarze PL-WRu I F 460 i PL-WRu I Q 255 oraz trzyczęściowy homiliarz PL-WRu I F 663. Stwierdzenie jednej ręki w źródłach PL-Wn I2496 oraz PL-WRu I F 663 stanowi dodatkowe potwierdzenie pochodzenia graduału sprzed kanonizacji św. Stanisława (I253), gdyż w trzecim tomie homiliarza pojawia się już wzmianka o świętym należąca do pierwotnej warstwy rękopisu (f. 36r, 2 kol.). Jeden z kopistów - najprawdopodobniej ten sam, który zapisał tekst literacki - sporządził zapis muzyczny w graduale i obu lekcjonarzach (PL-WRu I F 46o, PL-WRu I Q 255). Z kolei autorstwo iluminacji graduału wydaje się należeć do tegoż artysty, który zdobił lekcjonarz PL-WRu I Q 255 i homiliarz PL-WRu I F 663.

W świetle tych ustaleń nieprawdziwe okazują się niektóre dane z opisu rękopisu w inwentarzu lwowskim: po pierwsze, rękopis nie pochodzi z I360 r., tylko powstał nieco ponad wiek wcześniej, po drugie, nie jest to księga św. Jadwigi, jako że święta zmarła kilka lat przed sporządzeniem rękopisu (I243 r.). Zakwestionowanie „jadwiżańskiej” proweniencji księgi nie wyklucza jednak jej proweniencji trzebnickiej, szczególnie biorąc pod uwagę fakt, iż cysterki trzebnickie były wówczas pod jurysdykcją opata lubiąskiego (!), na którym spoczywała odpowiedzialność za wyposażenie filialnego klasztoru ${ }^{61}$. Posługiwanie się tym rękopisem w opactwie trzebnickim wydaje się wręcz bardzo prawdopodobne, bowiem na folio Ir, gdzie jakiś czas po sporządzeniu księgi zanotowano opatrzony rubryką „In festo sancte Hedwigis" formularz ku czci św. Jadwigi z dwoma wersetami allelujatycznymi Veni electa oraz $O$ felix Hedwigis (f. Ir), znajduje się dodatkowo zapis „In canonizatione beate Hedwigis" odnoszący się do wersetu Veni electa (?) sugerujący dopisanie śpiewów ku czci św. Jadwigi na okazję kanonizacji świętej (I267 r.). Rubryk o podobnej treści (z określeniem „beate”) nie spotykamy w żadnym innym źródle. Co więcej, ta sama ręka wpisała tenże formularz ku czci św. Jadwigi (tym razem z jednym wersetem allelujatycznym Veni electa) w nieco starszym graduale lubiąskim I F $4 \mathrm{I} 4$ - tym samym, w którym zidentyfikowano jedną rękę także w czternastowiecznych dopisach sekwencji występujących w obu księgach - w tym przypadku tylko z jedną rubryką:

60 Ze względu na brak liniatury pierwszy element clivis jest bardziej „giętki” - podobnie jak w przypadku zapisów tego typu (bez liniatury) w lekcjonarzu PL-WRu I F 460.

6I Helena Szwejkowska, Biblioteka klasztoru cysterek w Trzebnicy, Wrocław 1955, s. 7; Andrzej Wałkówski, „Wpływ skryptorium klasztoru cystersów w Pforcie na dokument lubiąski do końca XIII w.”, Nasza Przesztość 83 (1994), s. 204; Mateusz Siuchniński, „Pochodzenie i pierwotna przynależność zakonna konwentu cysterek w Trzebnicy”, Roczniki Historyczne I2 (1936) nr 2, s. 196-197. 
„In festo sancte Hedwigis”. Sporządzenie zapisów na f. Ir na okoliczność uroczystości związanych z kanonizacją świętej potwierdzałyby cechy paleograficzne pisma muzycznego, wskazujące na II poł. XIII wieku. W świetle dotychczasowych badań nad repertuarem chorałowym w księgach polskich ${ }^{62}$, graduał PL-Wn I2496 IV zawierałby najstarszy przekaz wersetu allelujatycznego $O$ felix Hedwigis (f. Ir) - do tej pory za najstarsze źródło tego śpiewu uznawano czternastowieczny rękopis I F 4I $7^{63}$.

Graduał PL-Wn I2496 IV, bez wątpienia sporządzony w skryptorium lubiąskim (ok. I250), najprawdopodobniej przeznaczony był dla sióstr z Trzebnicy. Byłby zatem rzeczywiście kodeksem „trzebnickim”, jak ujmuje to inwentarz lwowski. Księga nie miała jednak żadnego związku z samą św. Jadwigą, mogła ewentualnie być darem mnichów lubiąskich dla jej córki Gertrudy ${ }^{64}$, ówczesnej ksieni klasztoru trzebnickiego.

Jak wynika z opisu PL-Wn I2496 IV w inwentarzu rękopisów Biblioteki Baworowskich, graduał został nabyty po Johannie Theodorze Mosewiusie z Wrocławia. Sformułowanie „nabyty po” wskazywałoby, iż został zakupiony już po śmierci dawnego właściciela księgi, tj. po roku ı858. Jako że zasadniczy trzon kolekcji Wiktora Baworowskiego powstał w 1. I855-60, można by przypuszczać, iż księga wzbogaciła jego księgozbiór około I86o r., z pewnością zaś znalazła się we Lwowie przed rokiem I89ı, bowiem już w styczniu I892 r. ukazała się lista rękopisów opublikowana przez Kętrzyńskiego zawierająca tenże graduał. Johann Theodor Mosewius (I788-I858) związany był ze środowiskiem wrocławskim (szczególnie uniwersyteckim), gdzie od I8I6 r. prowadził ożywioną działalność artystyczną, przede wszystkim jako dyrygent, śpiewak i aktor ${ }^{65}$. Założyciel wrocławskiej Singakademie (I825) a także Verein für Kirchenmusik (I8I9) od I827 r. został zatrudniony jako wykładowca historii muzyki XVI-XVIII w., z kolei od roku I83I pełnił funkcję uniwersyteckiego dyrektora muzycznego. Idąc śladem berlińskich dokonań Mendelssohna, uczynił dziewiętnastowieczny Wrocław jednym z centrów kultywowania twórczości Jana Sebastiana Bacha ${ }^{66}$.

Wskutek edyktu sekularyzacyjnego (I8Io r.) do wrocławskiej Biblioteki Uniwersyteckiej trafiły księgozbiory i archiwa ze śląskich klasztorów, w tym trzebnickiego ${ }^{67}$.

62 Chodzi tu o księgi przechowywane w zbiorach polskich.

63 Do tej pory za najstarsze źródło wersetu allelujatycznego O felix Hedwigis uznawano graduał PL-WRu I F 4I7, zob.: Jerzy Pikulik, Śpiewy Alleluja o świętych, Warszawa 1995, s. I99-20I.

64 Kamil Wiącek, „Rozwój kultu św. Jadwigi Śląskiej w Wielkopolsce”, Studia Paradyskie 29 (2019), s. $189-204$.

65 Mosewius znany jest przede wszystkim jako propagator twórczości wokalno-instrumentalnej Bacha, a także Händla, Mozarta, Beethovena i in., zob. Portal Muzeum Uniwersytetu Wrocławskiego, http:// mbd.muzeum.uni.wroc.pl/dzieje-uniwersytetu/profesorowie-przed-1945-r/johann-theodor-mosevius, dostęp 3I VIII 2020.

66 George Grove, Lothar Hoffmann-Erbrecht, Mosewius, Johann Theodor, w: Grove Music Online, https://doi.org/IO.I093/gmo/9781561592630.article.I9194, dostęp 3I VIII 2020.

67 Biblioteka ówczesnego uniwersytetu znajdowała się w budynku klasztoru kanoników regularnych na Wyspie Piaskowej, który po sekularyzacji klasztorów został przeznaczony na Centralną Bibliotekę, zob.: H. Szwejkowska, Biblioteka, s. Iо, 80. 
Podczas gdy trzebnickie muzykalia zostały przez samego Johanna Gustava Gottlieba Büschinga - odpowiedzialnego za przejmowanie i uporządkowanie bibliotek częściowo oddane ówczesnemu kierownikowi chóru w Trzebnicy, księgi chorałowe miały zostać w całości zabrane do Wrocławia. Niestety, ze względu na oklejenie wewnętrznej strony okładki graduału kartą ochronną - jak się wydaje, już w Bibliotece Baworowskich - nie da się stwierdzić, czy księga miała proweniencyjną nalepkę Büschinga. Biorąc jednak pod uwagę dzieje księgozbioru trzebnickiego, jak też szczególną pozycję Mosewiusa na Uniwersytecie Wrocławskim, wydaje się, iż graduał trafił w jego ręce po sekularyzacji klasztoru w okresie działalności dydaktycznej muzyka na uniwersytecie ${ }^{68}$.

\section{FRAGMENTY}

Rękopisy PL-Wn I2497 IV i PL-Wn I2498 IV wyraźnie różnią się między sobą pod względem paleograficznym (por. il. 2 i 3 z il. 5). Zapisy muzyczne w PL-Wn I2497 IV należą do rąk dwóch skryptorów (il. 2-3), którzy sporządzili je w dość odległym od siebie czasie. Jeszcze inną tradycję piśmienniczą prezentuje notacja muzyczna kart, którymi posłużono się do oklejenia oprawy źródła (il. 4). Najstarszą część fragmentu stanowi jego pierwsza karta zawierająca pismo muzyczne - system neum mieszanych metzeńsko-gotyckich - charakterystyczne dla czternastowiecznych źródeł (il. 2) ${ }^{69}$. Jako podstawowy znak sylabiczny występuje tu punctum z cienką kreseczką wprowadzającą, często też z podobną kreseczką pociągniętą do góry po jego prawej stronie. Sporadycznie pojawia się izolowana virga z dość grubą laseczką zwężającą się ku dołowi i bardzo charakterystyczną skierowaną w prawo - jeszcze nie przybierającą kształtu regularnego rombu - główką kończącą się delikatnym pociagnnięciem pióra w górę (cienką, krótką kreseczka). Tego typu virga często występuje w czternastowiecznych cysterskich źródłach notowanych pismem metzeńskim ${ }^{70}$. Zapis na pierwszej karcie z pewnością musiał powstać po I3I8 r., kiedy to zostało ostatecznie wprowadzone święto Bożego Ciała ${ }^{71}$, bowiem na stronie verso widnieje zapis „In memoriam Corporis Christi” (f. Iv). Dalsza, zasadnicza część fragmentu PL-Wn I2497 IV powstała

68 Według Szwejkowskiej, w I8I5 r. zasadniczą część księgozbioru trzebnickiego włączono do ogólnych zasobów Biblioteki Uniwersyteckiej, z kolei muzykalia miały zostać przekazane w I8ı9 r. do Akademickiego Instytutu Śpiewu (autorce musiało chodzić o Królewski Akademicki Instytut Muzyki Kościelnej - Königliches Akademisches Institut für Kirchenmusik założony w I8I5 r.), zob.: H. Szwejkowska, Biblioteka, s. Io, 8 o.

69 W inwentarzu rękopisów Biblioteki Narodowej pierwsza karta PL-Wn I2497 IV jest datowana na wiek XV, por.: Inwentarz rękopisów, s. I69. Według Dominiki Grabiec, karta mogła powstać zarówno w ciągu XV w., jak też na początku tegoż wieku albo nawet w XIV stuleciu, zob.: D. Grabiec, „Formularz Mszy o Koronie Cierniowej", s. 22.

70 Np. PL-WRu I F 4I7, PL-WRu I F 397.

7I Edward Hinz, „Notacja muzyczna graduału rkp. II8/ı19 z Biblioteki Seminarium Duchownego w Pelplinie”, w: Musica Medii Aevi, red. Jerzy Morawski, t. 3, Kraków I969, s. 44. 
o ponad wiek później. Uwzględniając cechy pisma muzycznego - tendencje do rozłącznego traktowania elementów neumatycznych oraz masywne pociagnnięcie pióra - jak też zastosowanie do zapisu tekstu poszczególnych kompozycji dojrzałej antykwy, tę część fragmentu należałoby datować na wiek XVI (il. 3) ${ }^{72}$. Z kolei na kartach oprawy, obejmujących dwie antyfony maryjne $O$ radix Jesse i $O$ clavis David z grupy adwentowych tzw. wielkich antyfon „O”, występuje notacja czeska charakterystyczna szczególnie dla piętnastowiecznych źródeł (il. 4) ${ }^{73}$.

Zapisy muzyczne z fragmentu PL-Wn I2498 IV (il. 5), najprawdopodobniej powstały w XIV w., na pewno zaś po roku I3ı8 (podobnie jak pierwsza karta PL-Wn I2497 IV), o czym świadczą obecne na stronie verso śpiewy na święto Bożego Ciała. Podstawowy znak sylabiczny tej notacji stanowi charakterystyczne metzeńskie punctum, często o nieco falistym kształcie, z cienką kreseczką wprowadzającą i podobną wznoszącą się po jego prawej stronie. Występuje tu także kustosz w kształcie „2” (f. Iv) stanowiący niegdyś integralny element notacji cysterskiej (XII i XIII w.). Zastosowanie tego typu kustosza wraz z pismem metzeńskim jest dość powszechnym zjawiskiem w czternastowiecznych źródłach cysterskich na Śląsku, kiedy to w skryptoriach cysterskich coraz częściej posługiwano się pismem lokalnym (metzeńskim), pozostawiając przy tym charakterystyczny dla notacji cysterskiej kustosz. Trop cystersko-śląski wydaje się potwierdzać obecna tu sekwencja ku czci św. Jadwigi Consurge iubilans (il. 5) 54, której najstarsze znane przekazy pochodzą z tegoż czasu (XIV w.) z ksiąg śląskich, a najdawniejsze z nich powstały w skryptorium lubiąskim - graduał henrykowski PL-WRu I F 4 I7 oraz mszał wrocławski PL-WRk I4I z I323 r.75.

Datacje źródeł, poczynione głównie na podstawie cech pisma muzycznego, odbiegają od tych sugerowanych zarówno przez przedwojenny inwentarz Biblioteki Baworowskich, jak też najnowszy inwentarz rękopisów Biblioteki Narodowej. Czas powstania fragmentu PL-Wn I2497 IV podany w inwentarzu lwowskim (II poł. XIV w.) odpowiadałby jedynie pierwszej karcie rękopisu.

72 W inwentarzu rękopisów Biblioteki Narodowej ta część źródła jest datowana na wiek XVIII, zob.: Inwentarz rękopisów, s. I69. Dominika Grabiec sugeruje koniec XV w. lub wiek XVI jako czas powstania zapisów tej części fragmentu PL-Wn 12497 IV, zob.: D. Grabiec, „Formularz Mszy o Koronie Cierniowej", s. 22.

73 W tym przypadku zarówno inwentarz rękopisów Biblioteki Narodowej jak też Dominika Grabiec datują karty z oprawy o wiek wcześniej - na XIV stulecie, zob.: Inwentarz rękopisów, s. 169; D. Grabiec, „Formularz Mszy o Koronie Cierniowej”, s. 22.

74 Jest to najstarsza sekwencja o św. Jadwidze, występuje w ponad dwustu księgach liturgicznych, zob.: Erwin Mateja, „Postać św. Jadwigi Śląskiej w księgach liturgicznych”, w: Wkład św. Jadwigi Śląskiej $w$ kulturowe dziedzictwo Ślaska, red. Stanisław Araszczuk, Wrocław 2017, s. 83. Melodia Consurge jubilans jest oparta na melodii maryjnej sekwencji z XII w. Mittit ad virginem.

75 Jerzy Morawski, Polska liryka muzyczna w średniowieczu, Warszawa 1973, s. 23-25; Jerzy Morawski, "Ze studiów nad sekwencjami cysterskimi w Polsce”, w: Musica Medii Aevi, red. Jerzy Morawski, t. I, Kraków 1965, s. 82; Jerzy Pikulik, „Sekwencje polskie”, w: Musica Medii Aevi, red. Jerzy Morawski, t. 4, Kraków 1973, s. 4I. 
Zawartość liturgiczna obu fragmentów ma charakter dodatku do księgi zasadniczej. Jak już wspomniano, karta PL-Wn I2498 IV zawiera sekwencję ku czci św. Jadwigi oraz śpiewy na Boże Ciało. Bardziej rozbudowanym i różnorodnym pod względem repertuaru - pewnego rodzaju aneksem do graduału - jest fragment PL-Wn I2497 IV zawierający śpiewy liturgii mszalnej o różnym przeznaczeniu, z przewagą wersetów allelujatycznych:

- f. I: Gloria, wielkanocna sekwencja Victimae paschali laudes oraz Ecce panis angelorum (końcowy fragment sekwencji Lauda Sion),

- f. 2-5: wersety allelujatyczne ku czci świętych, cały formularz na święto Korony Cierniowej, kilka śpiewów maryjnych oraz Nunc rogemus przeznaczone na Zesłanie Ducha Świętego (zapisane z elementami notacji menzuralnej).

Szczególny zestaw śpiewów w PL-Wn I2497 IV jednoznacznie wskazuje na proweniencję cysterską. Pierwszorzędnym elementem identyfikującym liturgię cysterską w tym niedużym fragmencie jest formularz na święto Korony Cierniowej („In festo Spinae Coronae D. N. Iesu Ch.") ${ }^{76}$ charakterystyczny dla cysterskiej tradycji liturgicznej77:

IN Gaudeamus omnes in domino

GR Corona aurea super

Grv Quoniam praevenisti

AL Dulcis spina dulcis Christi

OF Lauda Ierusalem

CO Laetare mater nostra quia

Powszechne dopisywanie formularzy o Cierniowej Koronie w liturgikach cysterskich miało miejsce w wiekach XV i XVI, co potwierdzałoby datowanie tej części rękopisu PL-Wn I2497 IV (f. 2-5) na wiek $\mathrm{XVI}^{78}$.

76 Zarówno na podstawie dnia obchodu święta Korony Cierniowej, jak i doboru tekstów (śpiewów) proprium na to święto, wyodrębnić daje się dwie zasadnicze tradycje liturgiczne: cysterską, określaną jako parysko-cysterska ze względu na jej związek z Paryżem (święto obchodzono II sierpnia) oraz dominikańską, nazywaną również dominikańsko-diecezjalną (święto obchodzono 4 maja) ze względu na jej wpływ na liturgię licznych diecezji francuskich poza Paryżem. Obie tradycje - cysterska i dominikańska - znane były na terenach Polski, co potwierdzają zarówno kalendarze liturgiczne dokumentujące obie daty obchodów, jak i stosowane tu formularze mszalne odpowiadające obu tradycjom. Podobnie jak w przypadku diecezji francuskich, także na terenie Polski na obchody uroczystości Cierniowej Korony w ośrodkach diecezjalnych miała duży wpływ tradycja dominikańska, zob.: Jerzy Kopeć, „Przemiany ideowe pobożności pasyjnej na przykładzie kultu Cierniowej Korony Chrystusa", Studia Theologica Varsaviensia Io (1972) $\mathrm{nr} 2$, s. I55-193.

77 Formularz mszalny o Cierniowej Koronie Chrystusa właściwy liturgii cysterskiej charakteryzuje Jerzy Kopeć, zob.: J. Kopeć, „Przemiany ideowe pobożności pasyjnej”, s. I69-177. Zestawienia poszczególnych formularzy o Cierniowej Koronie pochodzących z ksiąg liturgicznych przechowywanych w zbiorach polskich dokonał Jerzy Pikulik. Jak wynika z tegoż zestawienia, formularz obecny w PL-Wn I2497 IV poza jednym przypadkiem - graduałem klarysek ze Starego Sącza, PL-Stk 2 - nie pojawia się w źródłach niecysterskich, zob.: J. Pikulik, Polskie graduaty, s. 239, 44I-442. Krótką charakterystykę tekstów śpiewów mszalnych przeznaczonych na święto Cierniowej Korony według cysterskiego formularza przedstawia Dominika Grabiec, zob.: D. Grabiec, „Formularz Mszy o Koronie Cierniowej”, s. 27-28.

78 J. Kopeć, „Przemiany ideowe pobożności pasyjnej”, s. I65-I66. Np. PL-PE Iı9, PL-Stk 2, PL-WRu I F 4I6, PL-WRu I F 4I8. 
Cysterskie pochodzenie badanego rękopisu tłumaczyłaby także obecność dość dużej liczby śpiewów maryjnych $\mathrm{w}$ tak krótkim fragmencie, a także zalecenie śpiewania antyfony maryjnej przed mszą świętą konwentualną (f. 5r), bowiem Matka Boża w zakonie cystersów była otaczana czcią w sposób szczególny ${ }^{79}$. Godne uwagi jest również zanotowanie $\mathrm{w}$ omawianym fragmencie wersetów allelujatycznych na dwa ważne dla cystersów święta - św. Bernarda ${ }^{80}$ oraz „De XI millibus virginum”" .

Bardzo cenną wskazówkę proweniencyjną stanowi wreszcie zapis na pięciolinii w jednym ze śpiewów alleluja (AL Ave stillans melle, „De Visitatione Beatae Mariae Virginis”) skrótów „orga.”, a nieco później „virg.” (zapis oryginalny). Są to najpewniej skróty wyrazów „organum” i „virgines” wskazujących, po pierwsze, na praktykę alternatim, polegającą na naprzemiennym wykonywaniu poszczególnych wersetów przez zespół śpiewaków i, w tym przypadku, organistę, po drugie, na wykonywanie partii wokalnej przez kobiety, a więc zakonnice ${ }^{82}$. Taki zapis sugerowałby przynależność rękopisu do zakonu żeńskiego. Ponadto, powszechna pod koniec średniowiecza praktyka alternowania z towarzyszeniem organów potwierdzałaby także szesnastowieczną datację rękopisu ${ }^{83}$.

W świetle faktu pochodzenia fragmentu PL-Wn I2497 IV z żeńskiego klasztoru cysterskiego nieprzypadkowa wydaje się obecność w rękopisie wersetu allelujatycznego ku czci św. Bartłomieja (In omnem terram) oraz dwóch wersetów ku czci św. Jadwigi - O felix Heduigis gaudens („In dies natalis”) oraz Veni electa mea („In dies canonisacionis”). Wpisy te przywodzą na myśl konwent cysterek w Trzebnicy z kościołem pw. Najświętszej Maryi Panny i św. Bartłomieja, gdzie św. Jadwiga była obdarzana szczególnym kultem jako fundatorka klasztoru, w którym spędziła ostatnie lata swojego życia, zmarła, i tamże spoczywają jej doczesne szczątki ${ }^{84}$.

Godne uwagi jest wymienienie dwóch różnych świąt ku czci św. Jadwigi - „In dies natalis” oraz „In dies canonisacionis”. Ze średniowiecznych kalendarzy liturgicznych znane jest przede wszystkim święto ku czci św. Jadwigi obchodzone I5, czasem I4 października ${ }^{85}$ występujące w kalendarzach cysterskich pod nazwą „In dies Natalis”.

79 Wszystkie konwenty cysterskie zgodnie z uchwałami kapituł generalnych miały być poświęcone Matce Bożej, a Matkę Bożą Wniebowziętą założyciele zakonu (św. Robert z Molesmes, św. Alberyk, św. Stefan Harding) obrali za szczególną patronkę, zob.: F. Wolnik, Liturgia, s. 244 i przyp. 17ı; Krystyna Kuźmak, „Bernard z Clairvaux. Kult”, w: Encyklopedia Katolicka, red. Feliks Gryglewicz, Romuald Łukaszyk, Zygmunt Sułowski, t. 2, Lublin 1976, szp. 306.

80 Dzień św. Bernarda obchodzono w zakonie cysterskim w najwyższym dwunastostopniowym rycie, zob.: F. Wolnik, Liturgia, s. 244.

8I J. Kopeć, „Przemiany ideowe pobożności pasyjnej”, s. 244. W I260 r. kapituła generalna w Cîteaux ustanowiła obchody święta św. Urszuli i jej Towarzyszek w całym zakonie cystersów (2I października); cystersi odegrali ważną rolę $\mathrm{w}$ popularyzacji święta poprzez propagowanie i translację relikwii Kolońskich Męczenniczek.

82 Na skróty „orga.” i ,virg” zwraca uwagę w swoim artykule również Dominika Grabiec, zob.: D. Grabiec, „Formularz Mszy o Koronie Cierniowej”, s. 22, przyp. 8.

83 J. Morawski, Polska liryka muzyczna, s. 263; Susi Ferfoglia, Msza alternatim we wtoskiej i francuskiej muzyce liturgicznej XVII wieku, Kraków 20II, s. IO-28.

84 F. Wolnik, Lituriga, s. 428-429.

85 Według kalendarza z brewiarza z Kamieńca Ząbkowickiego i Barda Śląskiego z II poł. XIV wieku. 
Nieco mniej powszechne jest święto przeniesienia relikwii św. Jadwigi („Translatio sanctae Hedwigis") z 25 sierpnia $^{86}$, które pojawia się tylko w kilku spośród piętnastu zachowanych kalendarzy cysterskich na Śląsku ${ }^{87}$, w tym w jednym z Trzebnicy. Jedynie kalendarz trzebnicki - zawarty w Liber Ordinarius z I573 r. - święto w tym dniu nazywa „In dies canonisacionis” (tak jak w PL-Wn I2497 IV) ${ }^{88}$. Co ciekawe, według kalendarza z trzebnickiego Liber Ordinarius, następnego dnia po translatio św. Jadwigi - tj. 26 sierpnia - w najwyższym rycie dwunastolekcyjnym obchodzono rocznicę poświęcenia kościoła własnego („Dedicatio ecclesiae”) ${ }^{89}$ - werset allelujatyczny na to właśnie święto zawiera także PL-Wn I2497 IV tuż obok wersetów ku czci św. Jadwigi.

Biorąc pod uwagę powyższe ustalenia - przede wszystkim zaś zważając na duże rozbieżności co do czasu powstania trzech źródeł, a stąd i ich odmienność pod względem paleograficznym - wydawałoby się, że rękopisy może łączyć co najwyżej wspólne skryptorium. Do innych wniosków prowadzi jednak porównanie fragmentów z późniejszymi dopisami w graduale (z uwzględnieniem wszystkich dodatków, również niemuzycznych), wskazując mianowicie, iż dwa fragmenty stanowić musiały końcową część graduału - tak jak to podejrzewano w inwentarzu lwowskim. Przynależność fragmentów do księgi mogła ujść uwadze dotychczasowych badaczy z tego powodu, iż w całości stanowią one dodatki późniejsze, powstałe w dość odległym odstępie czasowym w stosunku do części zasadniczej (oryginalnej), a także istotnie różniące się między sobą pod względem pisma i notacji muzycznej.

Swoiste ogniwo łączące fragment PL-Wn I2497 IV z graduałem stanowi należące do jednej ręki pismo muzyczne pierwszej karty fragmentu (il. 2) i czterech ostatnich kart graduału (por. il. 2 z il. 7) - notabene jest to właśnie ta sama ręka, którą zidentyfikowano w lubiąskim graduale I F 4I4 (czternastowieczny dodatek obejmujący zestaw sekwencji na f. I23r-I26, il. 6). Dodatkowym argumentem za przynależnością owego fragmentu do księgi jest rzymska numeracja na prawym marginesie (dopis późniejszy), która rozpoczyna się od cyfry VI na f. 86 graduału - prawdopodobnie dodana z tego powodu, iż oryginalna foliacja kończy się wraz z zakończeniem części de tempore na f. 85 - i jest kontynuowana do końca rękopisu do numeru XVIII, po czym jej ciąg dalszy - od XIX (il. 2) - następuje już we fragmencie (XIX-XXIII). Wydaje się, iż użytkownik graduału, chcąc dokończyć foliację rękopisu, uznał za zbędne wpisywanie całego numeru i zaczął od VI zamiast LXXXVI, pomijając dziesiątki.

Święto „Translatio sanctae Hedvigis” - tj. święto przeniesienia relikwii św. Jadwigi - łączy się z podniesieniem (elevatio) relikwii św. Jadwigi z grobu i uroczystym przeniesieniem do nowego sarkofagu w trzebnickim kościele, zob.: Stanisław Araszczuk, Kult świętej Jadwigi w świetle przedtrydenckich ksiag liturgicznych, Opole 1995 s. 70-75.

87 F. Wolnik, Liturgia, s. 253.

88 Ibid., s. 430.

89 Ibid., s. 243,245 . 
W graduale daje się zidentyfikować tęże samą rękę - śpiew Gloria na f. 95r - do której należy wpis sekwencji o św. Jadwidze z kilkoma innymi śpiewami na karcie przechowywanej pod sygnaturą PL-Wn I2498 IV. Na tejże karcie obecna jest wspomniana rzymska numeracja na prawym marginesie (XXVII, il. 5), która tym razem dodatkowo ujawnia brak trzech kart (XXIV-XXVI).

Godna uwagi jest także starta foliacja w prawym górnym rogu, która została dopisana na tych samych kartach co numeracja rzymska. Ślady po niej widoczne są na f. 86-98 graduału, a także w obu fragmentach. Dające się odczytać liczby na ostatniej karcie graduału (f. 98) - 98 - i ostatniej karcie fragmentu PL-Wn I2497 IV (f. 5) - I03 - poświadczają pierwotną ciągłość stron rękopisu w miejscu odłączenia fragmentu od graduału.

Badania porównawcze notacji muzycznych występujących w rękopiśmiennych fragmentach PL-Wn 12497 IV i PL-Wn I2498 IV z zapisami muzycznymi należącymi do późniejszej warstwy graduału nie pozostawiają wątpliwości, iż trzy źródła przechowywane pod odrębnymi sygnaturami stanowiły jedną księgę. Nurtujące pozostaje pytanie, kiedy i dlaczego fragmenty zostały odłączone od księgi?

Niemal pewne jest, iż do Biblioteki Baworowskich księga trafiła już z odłączonymi fragmentami. Przemawia za tym, po pierwsze, oklejenie oprawy jednego z fragmentów (PL-Wn I2497 IV) cennymi kartami pochodzącymi z innych rękopisów liturgicznych (według słów Kętrzyńskiego, Wiktor Baworowski w sposób szczególny troszczył się o kolekcję rękopiśmienna), po drugie, obecność na obu stronach tejże oprawy inicjałów nie należących do Baworowskiego - a więc poprzedniego właściciela (il. 4). Jak wynika z danych inwentarza lwowskiego, jego poprzednim właścicielem, tak jak i samego graduału, musiał być Johann Theodor Mosewius. Inicjały „J.Th.M.” (il. I6, s. 63) zamieszczone na oprawie wydają się być błędnie zidentyfikowane w inwentarzu rękopisów Biblioteki Narodowej i najprawdopodobniej należą właśnie do wrocławskiego muzyka.

Choć nie można z pewnością stwierdzić, iż samego odłączenia końcowego fragmentu graduału dokonał Mosewius, nawet jeśli inicjały rzeczywiście należą do niego, zważając jednak na jego dydaktyczną działalność na uniwersytecie wrocławskim jako wykładowcy historii muzyki XVI-XVIII w., nieprzypadkowe wydaje się odłączenie najmłodszej części księgi, którą stanowi szesnastowieczny palimpsest. Jak się wydaje, tego typu ingerencja w księgę musiała być wynikiem szczególnego zainteresowania fragmentem PL-Wn 12497 IV, gdyż następujące bezpośrednio po nim karty najwyraźniej pozostawiono luzem, na co wskazywałoby zaginięcie już we Lwowie czterech kart i zachowanie tylko jednej, zabezpieczonej tekturową oprawą, już w Bibliotece Baworowskich.

Związek fragmentów z katedrą lwowską, o którym w przypadku PL-Wn I2498 IV jest mowa u Kętrzyńskiego, zaś PL-Wn I2497 IV w inwentarzu, wydaje się nieuzasadniony. W żadnym z najstarszych opisów nie pojawia się wzmianka o łączności same- 
go graduału (PL-Wn I2496 IV) z katedrą lwowską. Niewykluczone, iż brak danych proweniencyjnych dotyczących tych rękopisów (fragmentów) wpłynął na przypisanie im pochodzenia z miejscowej katedry, skąd do kolekcji Baworowskich trafił inny bardzo cenny zabytek muzyczno-liturgiczny - Pontificale ecclesiae metropolitanae Halicensis postea Leopoliensis (PL-Wn I2499 IV).

\section{PODSUMOWANIE}

Przeprowadzone badania pozwoliły nie tylko na ustalenie właściwego czasu i miejsca pochodzenia rękopisów PL-Wn I2496 IV, PL-Wn I2497 IV i PL-Wn I2498 IV, lecz także na powrotne ich scalenie - trzy różnorodne pod względem paleograficznym źródła okazały się tworzyć niegdyś jedną całość. Najstarszą i główną jej część stanowił graduał powstały w skryptorium lubiąskim około I250 r. (pomiędzy rokiem I247-53). Jego wykonawcą był ten sam skryptor, który sporządził dwa lekcjonarze PL-WRu I Q 255 i PL-WRu I F 460 - oraz trzytomowy homiliarz PL-WRu I F 663, z kolei autorem ornamentyki był iluminator zdobiący lekcjonarz PL-WRu I Q 255 i homiliarz PL-WRu I F 663. Księga była przeznaczona dla sióstr w Trzebnicy (w klasztorze lubiąskim w tym czasie posługiwano się o kilka lat starszym graduałem PL-WRu I F 4I4), biorąc zaś pod uwagę jej bardzo staranne wykonanie i bogate zdobienie, można przypuszczać, że była darem opata lubiąskiego dla samej córki św. Jadwigi - Gertrudy - która wówczas była ksienią klasztoru trzebnickiego. Sądząc po licznych wpisach na marginesach, które sukcesywnie dodawano na kartach graduału na przeciągu kolejnych stuleci - najprawdopodobniej przez mnichów lubiąskich - księga musiała być w ciągłym użyciu przynajmniej przez cztery wieki (od poł. XIII do poł. XVII w.). Jeden z najmłodszych dodatków stanowi zapis na marginesie (f. 65r) formularza ku czci św. Kazimierza kanonizowanego w I602 r. (notabene, uzupełnienie ksiąg formularzami ku czci tegoż świętego Jerzy Pikulik odnotowuje jedynie w rękopisach cysterskich $\left.{ }^{\circ}\right)$. Jak wynika z historii zbiorów trzebnickich, wszystkie księgi chorałowe, jak i większość biblioteki klasztornej, wskutek akcji Komisji Sekularyzacyjnej zostały zabrane przez Johanna Gustava Büschinga do Wrocławia. Najprawdopodobniej takiż los spotkał również jedyny znany nam graduał trzebnicki. We Wrocławiu kodeks trafić musiał w ręce Mosewiusa, który, jak można przypuszczać, odłączył najmłodszy fragment rękopisu (pięć kart) od księgi, zabezpieczając go oprawą, na której wpisał swoje inicjały, kilka zaś kart następujących bezpośrednio po nim prawdopodobnie pozostawił luzem. Po śmierci muzyka rękopis wraz z odseparowanymi fragmentami - pierwszym oprawionym i drugim w postaci luźnych kart (?) - sprzedano lwowskiemu bibliofilowi Wiktorowi Baworowskiemu (ok. I86o r.). Rękopisy w zbiorach Baworowskich przez dłuższy czas pozostawały nieopracowane

90 J. Pikulik, Polskie graduaty, s. 2I4. 
i nieopisane, nie posiadały też sygnatur, natomiast już po ich uporządkowaniu okazało się, iż cztery z pięciu luźnych kart (drugi fragment) zaginęły, pozostała zaś tylko jedna (zawierająca sekwencję o św. Jadwidze), którą zabezpieczono tekturową oprawą najprawdopodobniej podczas tegoż porządkowania. Ostatecznie graduał i jego dwa końcowe fragmenty - jeden liczący pięć kart, drugi tylko jedną - otrzymały odrębne sygnatury. $Z$ opisów inwentarza wynika, iż początkowo było wiadomo o ścisłym związku odłączonych fragmentów z graduałem, jednak z czasem - być może z powodu ich odmienności paleograficznej - informację o tym poddano w wątpliwość, a później w ogóle o tym zapomniano. Wśród lwowskich rękopisów, które po wojnie zasiliły zbiory Biblioteki Narodowej, znalazły się wszystkie trzy części graduału jako odrębne źródła, których wzajemnego związku już nawet nie podejrzewano.

Sam graduał - tj. jego zasadnicza, oryginalna część przechowywana obecnie pod sygnaturą PL-Wn I2496 IV - odkąd wszedł do zbiorów Biblioteki Narodowej, niejednokrotnie był uwzględniany w pracach muzykologów mediewistów. Poglądy badaczy różniły się zarówno w kwestii datacji rękopisu, jak też jego proweniencji. Najbardziej odbiegającą od rzeczywistości opinię na temat pochodzenia graduału zaprezentował Jerzy Morawski, datując księgę aż na przełom XIII/XIV w. i przypisując jej żarnowiecką proweniencję ${ }^{91}$.

W świetle przeprowadzonych badań rękopis, choć sporządzony w skryptorium lubiąskim, wolno nazwać „Graduałem Trzebnickim”. Zawarty w nim przekaz sekwencji o św. Jadwidze okazał się jednym z najstarszych, zaś wersetu allelujatycznego $O$ felix Hedwigis najstarszym istniejącym zapisem utworu. Ustalona na ok. I250 r. datacja kodeksu stawia go w grupie najdawniejszych śląskich zabytków muzyczno-liturgicznych.

\section{BIBLIOGRAFIA}

Araszczuk, Stanisław. Kult świętej Jadwigi w świetle przedtrydenckich ksiąg liturgicznych. Opole: Wydawnictwo Świętego Krzyża, 1995.

Statuta capitulorum generalium ordinis Cisterciensis ab anno III6 ad annum I786. Wyd. Josephus-Maria Canivez. Löwen: Bureaux de la Revue, I934 (= Bibliothèque de la Revue d'histoire ecclésiastique 2).

Ferfoglia, Susi. Msza alternatim we wtoskiej i francuskiej muzyce liturgicznej XVII wieku. Kraków: Wydawnictwo-Drukarnia Ekodruk s. c., $201 \mathrm{I}$.

Grabiec, Dominika. „Formularz Mszy o Koronie Cierniowej z fragmentu graduału I2497 IV ze zbiorów Biblioteki Narodowej w Warszawie”. W: Textus et Pictura. Średniowieczny kodeks rękopiśmienny jako nośnik treści, znaczeń i wartości artystycznych, red. Monika Jakubek-Raczkowska, Marta Czyżak. T. 2, Studia nad skryptorium i spuścizna rękopiśmienna

9I J. Morawski, Średniowiecze, s. 349. 
średniowiecza, 2I-3I. Toruń: Wydawnictwo Naukowe Uniwersytetu Mikołaja Kopernika, 2019.

Hinz, Edward. „Notacja muzyczna graduału rkp. II8/ı19 z Biblioteki Seminarium Duchownego w Pelplinie". W: Musica Medii Aevi, red. Jerzy Morawski. T. 3, 43-58. Kraków: PWM, 1969.

Inwentarz rękopisów do potowy XVI wieku w zbiorach Biblioteki Narodowej. Opr. Jerzy Kaliszuk, Sławomir Szyller. Warszawa: Biblioteka Narodowa, 2012.

Jażdżewski, Konstanty Klemens. Lubiąż. Losy i kultura umystowa ślaskiego opactwa cystersów (II63-I642). Wrocław: Wydawnictwo Uniwersytetu Wrocławskiego, I992.

Kętrzyński, Wojciech. „Biblioteka Wiktora hr. Baworowskiego we Lwowie”. Teka konserwatorska. Rocznik Kota C.K. konserwatorów starożytnych pomników Galicyi wschodniej I (I892).

Kołodziejczak, Zenon. „Historia chorału gregoriańskiego w Polsce”. W: Thesaurus musicae sacrae summa cura servetur et foveatur, red. Stanisław Dąbek, Ireneusz Pawlak. Lublin: Polihymnia, 2004.

Kopeć, Jerzy. „Przemiany ideowe pobożności pasyjnej na przykładzie kultu Cierniowej Korony Chrystusa". Studia Theologica Varsaviensia IO, nr 2 (1972): I55-193.

Kuźmak, Krystyna, „Bernard z Clairvaux. Kult”. W: Encyklopedia Katolicka, red. Feliks Gryglewicz, Romuald Łukaszyk, Zygmunt Sułowski. T. 2, 306. Lublin: KUL, 1976.

Kuźmak, Krystyna. „Edmund z Abingdon”. W: Encyklopedia Katolicka, red. Romuald Łukaszyk, Ludomir Bieńkowski, Feliks Gryglewicz. T. 4, 66I-662. Lublin: Towarzystwo Naukowe Katolickiego Uniwersytetu Lubelskiego, 1989.

Maciejewski, Tadeusz. „Kyriale cysterskie w najstarszych rękopisach polskich: XIII i XIV wiek”. W: Musica Medii Aevi, red. Jerzy Morawski. T. 3, 59-90. Kraków: PWM, I969.

Mateja, Erwin. „Postać św. Jadwigi Śląskiej w księgach liturgicznych”. W: Wktad św. Jadwigi Ślaskiej w kulturowe dziedzictwo Ślaska, red. Stanisław Araszczuk, 8I-92. Wrocław: Papieski Wydział Teologiczny, 2017.

Morawski, Jerzy. Polska liryka muzyczna w średniowieczu. Warszawa: PWN, 1973.

Morawski, Jerzy. Średniowiecze. Cz. I. Warszawa: Sutkowski Edition, 2006 (= Historia Muzyki Polskiej I).

Morawski, Jerzy. „Ze studiów nad sekwencjami cysterskimi w Polsce”. W: Musica Medii Aevi, red. Jerzy Morawski. T. I, 69-88. Kraków: PWM, I965.

Nowiński, Janusz. „Cystersi propagatorami kultu relikwii św. Urszuli i jej Towarzyszek (Undecim Milium Virginum) - wybrane przykłady”. Saeculum Christianum 2I (20I4): 6I-72.

Pikulik, Jerzy. Polskie graduaty średniowieczne. Warszawa: Wydawnictwo Uniwersytetu Kardynała Stefana Wyszyńskiego, 20oI.

Pikulik, Jerzy. „Sekwencje polskie”. W: Musica Medii Aevi, red. Jerzy Morawski. T. 4, 7-I25. Kraków: PWM, 1973.

Pikulik, Jerzy. Śpiewy Alleluja o świętych. Warszawa: Wydawnictwo Uniwersytetu Kardynała Stefana Wyszyńskiego, I995.

Siuchniński, Mateusz. „Pochodzenie i pierwotna przynależność zakonna konwentu cysterek w Trzebnicy". Roczniki Historyczne I2, nr 2 (1936): I87-197.

Solecki, Witold. Analiza źródtowa rękopisu muzycznego ms. BAW. 2 z Biblioteki Narodowej $w$ Warszawie. Praca magisterska, Uniwersytet Kardynała Stefana Wyszyńskiego, I982.

Szendrei, Janka. „Notacja liniowa w polskich źródłach chorałowych XII-XVI wieku”. W: Notae musicae artis. Notacja muzyczna w źródtach polskich XI-XVI wieku, red. Elżbieta Witkowska-Zaremba, I87-28I. Kraków: Musica Iagellonica, I999. 
Szocki, Józef. „Księgozbiór Wiktora Baworowskiego - lwowskiego kolekcjonera i fundatora biblioteki”. W: Lwów: miasto, społeczeństwo, kultura, red. Henryk W. Żaliński, Kazimierz Karolczak, 447-455. Kraków: Wydawnictwo Naukowe WSP, 1998 (= Studia z Dziejów Lwowa 2).

Szwejkowska, Helena. Biblioteka klasztoru cysterek w Trzebnicy. Wrocław: Wrocławskie Wydawnictwo Naukowe, 1955 .

Tabor, Dariusz. Iluminacje cysterskich kodeksów śląskich XIII wieku. Kraków: Księgarnia Akademicka, 2004.

Tchórzewska-Kabata, Halina, red. Nad ztoto droższe. Skarby Biblioteki Narodowej. Warszawa: Biblioteka Narodowa, 2000.

Wałkówski, Andrzej. „Lubiąskie rękopisy muzyczne z XIII w. na tle badań nad skryptoriami cystersów. Nutacja diastematyczna”. Acta Universitatis Lodziensis. Folia Librorum I8 (20I4): 9-34.

Wałkówski, Andrzej. Skryptoria cystersów filiacji portyjskiej na Ślasku do końca XIII w. Zielona Góra-Wrocław: WSP, 1996.

Wałkówski, Andrzej. „Wpływ skryptorium klasztoru cystersów w Pforcie na dokument lubiąski do końca XIII w.”. Nasza Przesztość 83 (1994): 203-247.

Wiącek, Kamil. „Rozwój kultu św. Jadwigi Śląskiej w Wielkopolsce”. Studia Paradyskie 29 (2019): 189-204.

Wolnik, Franciszek. Liturgia śląkich cystersów w średniowieczu. Opole: Wydawnictwo Wydziału Teologicznego Uniwersytetu Opolskiego, 2002.

ON THREE MUSICAL-LITURGICAL SOURCES FROM THE BAWOROWSKI COLLECTION, HELD IN THE NATIONAL LIBRARY OF POLAND

My research into three musical-liturgical manuscripts from the Baworowski collection, now kept in the National Library (the gradual PL-Wn I2496 IV and the fragments PL-Wn I2497 IV and PL-Wn I2498 IV) revises our knowledge about them and sheds light on doubts and contradictions resulting from the oldest descriptions of these sources.

These three palaeographically different sources from periods very distant from one another turn out to have once formed a single volume. The two fragments as a whole represent a later addition to the gradual, one that was separated from the main section probably during the first half of the nineteenth century.

The gradual itself, or rather its main, original part, was compiled around 1250 at the Lubiąż scriptorium for the Cistercian nuns of Trzebnica, possibly as a gift for St Hedwig of Silesia’s daughter Gertrude. Owing to the secularisation of the Silesian monasteries (in I8Io), the manuscript was most likely taken from Trzebnica to Wrocław, but it did not end up in the University Library. Instead, like the bulk of the monastic collection, it became the private property of Wrocław-based musician J.T. Mosewius. After his death, with the fragments already separated from the body of the gradual, it joined Wiktor Baworowski's collection in Lviv, where the three parts of the volume received separate shelf marks. Following the Second World War (in 1945), the gradual and the two fragments arrived at the National Library, already as three separate sources unrelated in any way except for their Lviv provenance. 
In the light of research, the manuscript, although prepared at the Lubiąż scriptorium, may be called the 'Trzebnica Gradual'. It belongs to the oldest musical-liturgical sources preserved in Poland and contains the oldest surviving source of the Alleluia verse $O$ felix Hedwigis ( PL-Wn I2486 IV, fol. Ir), as well as one of the oldest sources of the sequence to St Hedwig Consurge jubilans (PL-Wn I2498 IV).

Translated by Tomasz Zymer

Słowa kluczowe / key words: Cystersi / Cistercians, graduał / gradual, notacja cysterska / Cistercian notation, liturgia / liturgy, skryptorium lubiąskie / Lubiąż scriptorium, cysterki trzebnickie / Cistercian nuns in Trzebnica, O felix Hedwigis, Consurge iubilans, kolekcja Baworowskich / Baworowski collection.

Dr Irina Chachulska, adiunkt w Zakładzie Muzykologii Instytutu Sztuki PAN, wykłada także chorał gregoriański na II Wydziale Uniwersytetu Muzycznego Fryderyka Chopina. Absolwentka Instytutu Muzykologii KUL oraz Muzyki Kościelnej na UMFC. Jej główne obszary badawcze obejmują zagadnienia paleografii muzycznej, źródłoznawstwa i kodykologii oraz średniowiecznej liturgii i śpiewu Kościoła Zachodniego. Aktualnie prowadzi badania skoncentrowane wokół cysterskich średniowiecznych źródeł chorałowych. Prowadzi polską sekcję bazy CANTUS (Plainchant Sources in Poland - Cantus Planus in Polonia), jest członkinią zespołu badawczego Manuscripta.pl - A guide to medieval manuscript books in Polish collections. irina.chachulska@ispan.pl

\section{Film o kwartalniku MUZYKA}

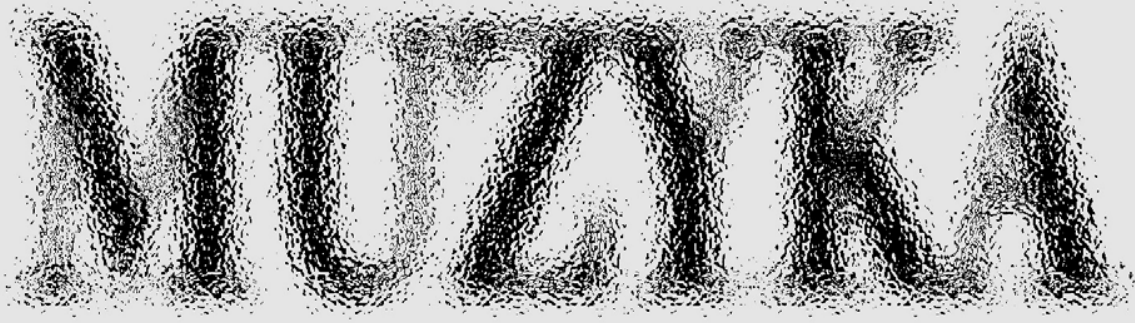

